$1-1-2013$

\title{
Employers United: An Empirical Analysis of Corporate Political Speech in the Wake of the Affordable Care Act
}

\author{
Elizabeth Weeks Leonard \\ University of Georgia Main Campus, weeksleo@uga.edu \\ Susan Scholz \\ University of Kansas School of Business \\ Raquel Meyer Alexander \\ Washington \& Lee University
}

p bepress SSRN

\section{Repository Citation}

Elizabeth Weeks Leonard, Susan Scholz, and Raquel Meyer Alexander, Employers United: An Empirical Analysis of Corporate Political Speech in the Wake of the Affordable Care Act, 38 J. Corp. L. 217 (2013), Available at: https://digitalcommons.law.uga.edu/fac_artchop/1046

This Article is brought to you for free and open access by the Faculty Scholarship at Digital Commons @ University of Georgia School of Law. It has been accepted for inclusion in Scholarly Works by an authorized administrator of Digital Commons @ University of Georgia School of Law. Please share how you have benefited from this access For more information, please contact tstriepe@uga.edu. 


\section{Employers United: An Empirical Analysis of Corporate Political Speech in the Wake of the Affordable Care Act}

\section{Elizabeth Weeks Leonard,* Susan Scholz,** and Raquel Meyer Alexander***}

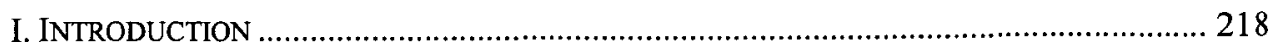

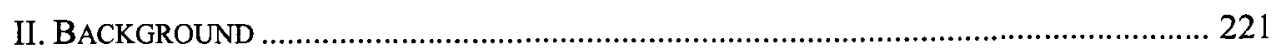

A. Brief History of Retiree Drug Plans .......................................................... 221

B. Retiree Drug Subsidy ............................................................................. 223

C. Post-ACA SEC Disclosures and Congressional Investigation ....................... 225

III. SEC REQUIREMENTS AND ACCOUNTING STANDARDS ...................................... 228

A. SEC Disclosure Requirements................................................................... 228

1. Scheduled Disclosure: Forms 10-K and 10-Q .................................... 228

2. Current Reports: Form 8-K .................................................................. 229

B. Generally Accepted Accounting Principles ................................................. 231

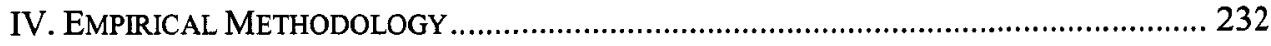

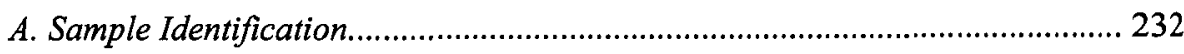

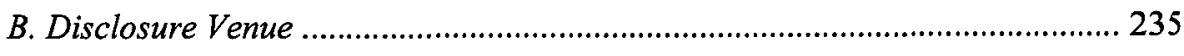

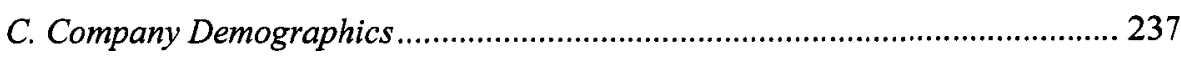

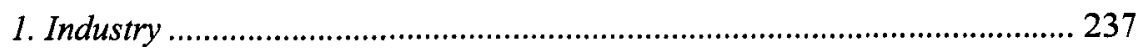

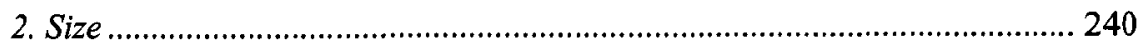

a. Number of Employees...................................................................... 240

b. Assets and Market Capitalization ................................................... 242

D. Lobbying and Subsequent SEC Disclosure ............................................... 243

E. Market Nonresponse .......................................................................... 245

1. Prediction Market for ACA Enactment ............................................. 245

\footnotetext{
* Associate Professor, University of Georgia School of Law. The authors are grateful for comments from David Hyman, Susan Cancelosi, Usha Rodrigues, and participants at the University of Arkansas School of Law, University of Indiana-Bloomington School of Law, Midwestern Law \& Economics Association Annual Meeting, and Southeastern Association of Law Schools Annual Meeting, and excellent research assistance by Brad Flynt, Katie McCabe, Laura Armstrong, and William Ellison. Intrade archive data was generously provided by Professor Panos Ipeirotis.

** Associate Professor and Harper Faculty Fellow, University of Kansas School of Business.

*** Associate Professor, Washington \& Lee University, Williams School of Commerce, Economics, and Politics.
} 
V. FINDINGS AND IMPLICATIONS

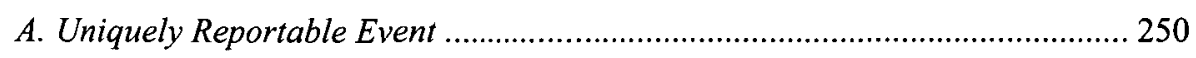

B. Government Regulation of Corporate Political Speech ................................ 252

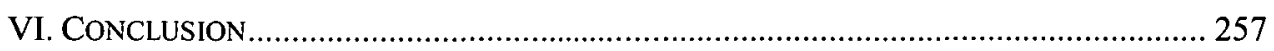

\section{INTRODUCTION}

Securities and Exchange Commission (SEC) Form 8-K offers a unique platform for corporate political speech. The requirement that publicly traded firms issue real-time disclosures of material changes to their expected results ${ }^{1}$ both requires and allows companies to publicly comment on the financial impact of newly enacted laws. Our unique empirical study examines one such disclosure episode that immediately followed the enactment of the Patient Protection and Affordable Care Act (ACA), on March 23, $2010 .^{2}$ Following passage of that historic legislation, close to 150 companies wrote off a total of $\$ 5$ billion against their 2010 earnings, triggered by just one relatively minor provision of the ACA. ${ }^{3}$ These write-offs signaled the potentially crippling impact of the entirety of the ACA on employers and the feasibility of continuing to offer employee health insurance plans. Officials in Congress and President Obama's Administration quickly rebuked the firms for unnecessarily alarming the public about the negative effects of the Administration's signature legislation. ${ }^{4}$

The Supreme Court's June 28, 2012 decision in National Federation of Independent Business v. Sebelius, ${ }^{5}$ upholding virtually all of the ACA, means that the law is here to stay, barring dramatic changes in the November 2012 elections and repeal of the legislation. Meanwhile, employers continue to express serious concerns about the future of employer-based health insurance. ${ }^{6}$ We recognize that SEC-compelled speech may,

1. See infra Part III.A (describing SEC disclosure requirements).

2. Patient Protection and Affordable Care Act (ACA), Pub. L. No. 111-148, 124 Stat. 119 (2010), amended by Health Care and Reconciliation Act of 2010, Pub. L. No. 111-152, 124 Stat. 1029 (2010).

3. See infra Part IV (describing data derived from comprehensive survey of SEC filings).

4. See infra Part II.C (describing the response by the Obama Administration).

5. Nat'l Fed'n of Indep. Bus. v. Sebelius, 132 S. Ct. 2566, 2572-74 (2012) (upholding the minimum coverage requirement under federal taxing power but limiting federal government's enforcement authority for Medicaid).

6. See Towers Watson, Nat'l Bus. GRP. ON Health, 2012 Employer SuRVEy on PuRchasing VALUE IN HEALTH CARE 3 (2012), available at http:/www.towerswatson.com/assets/pdf/6556/Towers-WatsonNBGH-2012.pdf (noting that health care costs continue to rise in 2012, and only $23 \%$ of surveyed employers are confident they will continue to offer health care benefits over the next ten years); NAT'L BUS. GRP. ON Health, Survey Report: Large Employers' 2012 Health Plan Design Changes 5 (Aug. 2011) [hereinafter LARGE EMPLOYERS], available at http://capsules.kaiserhealthnews.org/wp-content/uploads/2011/ 08/2012-NBGH-Plan-Design-Survey-Report-Embargoed-Edition.pdf (finding that "[a]s regulations from the Affordable Care Act have come into effect, employers have had to re-evaluate their health plan designs to conform to regulations and control rising costs"); Shubham Singhal et al., How U.S. Health Care Reform Will Affect Employee Benefits, MCKINSEY Q. (June 2011), http://www.mckinseyquarterly.com/How_US_health_care 
under certain circumstances, carry a political message and the implications of extending First Amendment protection to those statements. ${ }^{7}$ We also recognize that the Supreme Court recently extended even greater solicitude to corporate free speech rights and political participation in Citizens United v. Federal Election Commission. ${ }^{8}$ But what we find more troubling is the government's potential to chill otherwise accurate disclosures by damning them as political gamesmanship. ${ }^{9}$

Passage of the ACA did little to quell employers' persistent concerns about escalating health care costs and their ability to continue offering health insurance benefits to retired and active employees. ${ }^{10}$ Several provisions of the ACA, including the "Cadillac

reform will affect employee benefits 2813 (finding that overall, 30\% of employers will "definitely or probably" stop offering employee health benefits after 2014, and more than $50 \%$ of employers with "high awareness of reform" will do so); Kelly Kennedy et al., What's Next in Health Care? Implementation of Law Goes Ahead, USA TODAY, June 29, 2012, http://www.usatoday.com/money/industries/health/story/2012-0628/health-care-ruling-whats-next/55900370/1 (suggesting that "[e]mployers who fought the law as a job killer will now have to come to grips with it and minimize the parts they don't like").

7. See generally Tom Bennigson, Nike Revisited: Can Commercial Corporations Engage in NonCommercial Speech?, 39 CONN. L. REV. 379 (2006) (urging that all speech by commercial corporations, regardless of content, be considered "commercial speech" for First Amendment purposes); Henry N. Butler \& Larry E. Ribstein, Corporate Governance Speech and the First Amendment, 43 U. KAN. L. REV. 163 (1994) (distinguishing proxy speech, which should receive First Amendment scrutiny, from speech related to continuous disclosure, sale of securities, insider trading, and takeovers, which, although arguably commercial speech, may not be appropriate for constitutional free speech regulation); Lloyd L. Drury III, Disclosure Is Speech: Imposing Meaningful First Amendment Constraints on SEC Regulatory Authority, 58 S.C. L. REV. 757 (2007) (finding sufficient similarities between SEC disclosures and advertising to justify application of commercial speech protections); Antony Page \& Katy Yang, Controlling Corporate Speech: Is Regulation Fair Disclosure Unconstitutional?, 39 U.C. DAVIS L. REV. 1 (2005) (arguing against First Amendment protection for SEC "Regulation Fair Disclosure" speech, which requires companies that disclose "material non-public" information to certain private audiences also to make that information available publicly); Michael $\mathrm{R}$. Siebecker, Corporate Speech, Securities Regulation, and an Institutional Approach to the First Amendment, 48 WM. \& MARY L. REV. 613 (2006) (applying an institutional approach to advocate keeping securities mandatory reporting and disclosure requirements out of First Amendment's reach); Nicholas Wolfson, The First Amendment and the SEC, 20 CONN. L. REV. 265 (1988) (concluding that corporate proxy statements, prospectuses, accounting statements, and similar statements should be fully protected by the First Amendment).

8. Citizens United v. Fed. Election Comm'n, 558 U.S. 50 (2010). For articles assessing the corporate political speech implications of Citizens United, see, e.g., Roger Coffin, A Responsibility to Speak: Citizens United, Corporate Governance and Managing Risks, 8 HASTINGS BUS. L.J. 103, 103 (2012) (arguing Citizens United "removed a critical barrier to corporate spending in elections"); Matthew A. Melone, Citizens United and Corporate Political Speech: Did the Supreme Court Enhance Political Discourse or Invite Corruption?, 60 DePaul L. REV. 29, 98 (2010) (concluding that Citizens United "will usher in a new era of corporate political dominance"); Larry E. Ribstein, The First Amendment and Corporate Governance, 27 GA. ST. U. L. REV. 1019, 1021 (2011) (stating that Citizens United "shifted the debate over corporate speech to corporate governance processes that authorize this speech"); Anne Tucker, Flawed Assumptions: A Corporate Law Analysis of Free Speech and Corporate Personhood in Citizens United, 61 CASE W. RES. L. REV. 497, 550 (2010) (arguing that Citizens United was based on false assumptions, which calls the Court's holding into question).

9. See infra Part V.B (discussing additional examples of corporate speech regulation in the context of the $\mathrm{ACA})$.

10. See, e.g., Josh Funk, Companies Say Health Care Costs Hard to Swallow, Boston GLoBE, Mar. 25, 2010 , http://www.boston.com/business/healthcare/articles/2010/03/25/companies_say_health_care_costs_hard_ to_swallow/ (noting that the "health care overhaul will cost U.S. companies billions," which could lead them to drop benefits); Douglas Holtz-Eakin, Labor Markets and Health Care Reform: New Results, AM. ACTION F. (May 2010), http://americanactionforum.org/files/LaborMktsHCRAAF5-27-10.pdf (noting various incentives in the ACA for employers to drop coverage for their employees and calculating amounts employers would have to 
tax" on high-cost health plans, ${ }^{11}$ restrictions on lifetime and annual benefits caps, ${ }^{12}$ the extension of dependent child coverage, ${ }^{13}$ employer pay-or-play penalties, ${ }^{14}$ and new disclosure and reporting requirements, will be potentially very costly for employers. ${ }^{15}$ Those changes are against a baseline of ever-increasing costs; in 2013, health care costs are expected to rise $7.5 \%$, which costs employers will either have to absorb, or find ways to reduce or offset. ${ }^{16}$

Although many ACA provisions will impact employers as they are implemented over the next several years, ${ }^{17}$ only one, involving a change in tax treatment for federal subsidies to employers, ${ }^{18}$ had an immediately reportable impact on firms' financial results in 2010. The ACA provision triggering the 147 companies' SEC filings purported merely to clarify tax treatment of a federal subsidy to employers offering prescription drug benefits to retired workers. Previously, employers accepting the federal retiree drug subsidy (RDS) could both exempt the subsidy amount from their taxable income and deduct that same amount as a business expense. ${ }^{19}$ Under the ACA, firms still may receive

pay to maintain coverage); TOWERS WATSON, HEALTH CARE REFORM: LOOMING FEARS MASK UNPRECEDENTED EMPLOYER OPPORTUNITIES TO MITIGATE COSTS, RISKS AND RESET TOTAL REWARDS (May 2010), available at http://www.towerswatson.com/assets/pdf/1935/Post-HCR_Flash_survey_bulletin_5_25 10(1).pdf (surveying over 650 employee benefits specialists, finding that "the overwhelming majority $(\overline{90 \%}) \overline{\text { of }}$ employers believe health care reform will increase their organization's health care benefit costs").

11. 26 U.S.C. $\$ 4980 \mathrm{I}(2006)$.

12. 42 U.S.C.A. $\$ 300$ gg-11 (West 2010).

13. Id. $\$ 300 \mathrm{gg}-14$.

14. 26 U.S.C. $\$ 4980 \mathrm{H}$.

15. See Employers Accelerate Efforts to Bring Health Benefit Costs Under Control, MERCER (Nov. 2011), http:/www.mercer.com/press-releases/national-survey-employer-sponsored-health-plans?siteLanguage $=100$ (listing various ACA provisions that concern employers, with the Cadillac tax being one of the greatest concerns).

16. U.S. Healthcare Costs to Rise 7.5\% in 2013: Report, FoxBusiness (June 6, 2012), http://www.foxbusiness.com/news/2012/05/31/us-healthcare-costs-to-rise-75-pct-in-2013-report/ (citing REUTERS). Estimates for health care spending increases vary widely. Compare Employers Accelerate Efforts to Bring Health Benefit Costs Under Control, supra note 15 (reporting an expected $5.7 \%$ increase in average total per-employee health benefit costs for 2012, down from $6.9 \%$ in 2010 and $6.1 \%$ on 2011), with 2012 Segal Health Plan Cost Trend Survey, SIBSON CONSUlTING (Sept. 27, 2011), http:/www.sibson.com/publications/ surveysandstudies/2012trendsurvey.pdf (projecting cost trends for all medical plan types to range from $9.6 \%$ to $10.4 \%$ in 2012 , down from $10.2 \%$ to $11.7 \%$ in 2011 ). Overall national health expenditures are expected to rise, especially once key provisions of the ACA are implemented in 2014. See Sean P. Keehan et al., National Health Expenditure Projections: Modest Annual Growth Until Coverage Expands and Economic Growth Accelerates, 37 HEALTH AFF. 1600 (2012), available at http://content.healthaffairs.org/content/31/7/1600.early (reporting that U.S. health care spending for 2011 to 2013 is projected to increase at a rate of $4 \%$, up from $3.8 \%$ in 2009 , but that spending will increase at $5.7 \%$ annual rate from 2011 to 2021 when major ACA provisions are in effect).

17. See generally LABOR, IMMIGRATION \& EMP. Benefits DIV., U.S. ChAMBER OF COMMERCE, Critical EMPloyer Issues IN THE PATIENT Protection AND AFfordable Care ACT (Apr. 26, 2010), available at http:/www.uschamber.com/sites/default/files/chambers/files/51910criticalemployerissuesinthe ppaca.pdf (analyzing employer impact from the ACA in detail).

18. 26 U.S.C. $\$ 139 A$ (2006), amended by Patient Protection and Affordable Care Act, Pub. L. No. 111 148, $\S 9012$, 124 Stat. 119 (2010) (eliminating deduction for expenses allocable to Medicare Part D subsidy) (effective date changed by Health Care and Education Reconciliation Act of 2010, Pub. L. No. 111-152, § 1407, 124 Stat. 1029).

19. Medicare Prescription Drug, Improvement, and Modernization Act of 2003, Pub. L. No. 108-173, § 1860D-22, 117 Stat. 2066 (codified at 42 U.S.C. $\S 1395$ w-132 (2006)) (listing special rules for employer- 
the subsidy tax-free but may no longer take the deduction. ${ }^{20}$

The narrative that the Obama Administration and ACA proponents told was that the firms' high-dollar write-offs were nothing more than sour grapes and disingenuous attempts to perpetuate the partisan battle, even after the ACA was finally and validly enacted. ${ }^{21}$ Our study tells a different story. First, we establish that the RDS write-offs were required under applicable SEC rules and consistent with financial accounting standards. Those firms issuing more prominent SEC disclosure statements regarding the RDS generally were the firms that experienced greater financial impact as a result of the change. Second, we note that a high percentage of firms issuing post-ACA Form 8-Ks actively and publicly opposed the RDS tax change proposal before it was enacted. Even if firms' SEC disclosures had the desired purpose and effect of reasserting their political objections to the ACA, their statements were also accurate, required, and expected. The Administration's response, more than the firms' disclosures, seem to have been politically motivated as an attempt to suppress corporate political speech critical of the newly enacted reforms.

Part II of this Article explains the historical and legal background of the RDS controversy. Part III describes the SEC and Financial Accounting Standards (FAS) rules that required the firms' disclosures. Part IV presents our empirical methodology and findings. Part V considers the broader implications of Form $8-\mathrm{K}$ as a corporate political speech venue and the government's attempts to control political messaging around the ACA.

\section{BACKGROUND}

We begin with a brief history of employer-based health insurance, with particular emphasis on retiree prescription drug plans. Next, we explain the statutory enactment of the RDS in 2003 and the tax code change to the RDS in 2010 , under the ACA. Finally, we discuss the political controversy that arose following several prominent firms' postACA-enactment SEC Form 8-K filings, reporting significant expected earnings shortfalls due to the RDS tax change.

\section{A. Brief History of Retiree Drug Plans}

Employer-based health insurance is a product of post-World War II wage-hour laws, ${ }^{22}$ favorable tax treatment for employee benefits, ${ }^{23}$ and union pressure on particular

sponsored programs).

20. See 26 U.S.C. $\S 139$ A (2006) (as amended) (detailing the elimination of the deduction).

21. See infra Part II.C (describing congressional investigation and the Obama Administration's response).

22. David A. Hyman \& Mark Hall, Two Cheers for Employment-Based Health Insurance, 2 YALE J. Health Pol'y L. \& Ethics 23, 23-43 (2001); Susan E. Cancelosi, Revisiting Employer Prescription Drug Plans for Medicare-Eligible Retirees in the Medicare Part D Era, 6 Hous. J. HEALTH L. \& POL'Y 85, 85-149 (2005).

23. See Bradley W. Joondeph, Tax Policy and Health Care Reform: Rethinking the Tax Treatment of Employer-Sponsored Health Insurance, 1995 BYU L. REV. 1229, 1229-61 (1995) (explaining how the tax code creates incentives for taxpayers to acquire health coverage through employment-related groups); see also Hyman \& Hall, supra note 22 (stating that the tax code was an impetus for the increase in employment-based coverage); Cancelosi, supra note 22, at 89 (describing the subsidy on employee benefits provided by the tax code). 
industries. ${ }^{24}$ Retiree health insurance initially was a relatively inexpensive add-on to employer health plans and an easy concession to unions. The Big Three automakers were among the first companies, in 1967 , to offer retiree health benefits. ${ }^{25}$ The federal Medicare program, enacted in 1965, provides comprehensive health coverage for retirees aged 65 and older. ${ }^{26}$ Accordingly, employers could supplement Medicare-eligible retirees' federal coverage at relatively little expense and provide short-term coverage to early retirees until they became Medicare-eligible. ${ }^{27}$ As the federal Age Discrimination in Employment Act of 1967 prohibits layoffs that target older workers, firms use generous retirement benefits as a carrot to encourage aging workers to retire. ${ }^{28}$

Employer-based prescription drug coverage was an especially valuable supplement because Medicare did not cover outpatient prescription drugs until relatively recently. ${ }^{29}$ As pharmacological treatments increasingly are used to manage chronic conditions suffered by many retirement-aged individuals, prescription drug coverage became more important to retirees and at the same time, drug plans became more expensive for employers. ${ }^{30}$ In general, employers' overall health care costs, for both active and retired workers, have continued to rise steadily in recent years. ${ }^{31}$ One study noted that "[d]ue to rising costs, some employers and employees have been economically forced to abandon employer-sponsored health benefits entirely." 32 Small employers, in particular, have difficulty bearing the costs of providing health insurance to employees. ${ }^{33}$

Retiree health plans are more vulnerable than plans for active workers. To support retiree plans, employers typically impose greater cost-sharing obligations, more restrictive drug-plan formularies, benefits caps, and increased time-in-service eligibility criteria. ${ }^{34}$ The increased costs of providing retiree prescription drug coverage has caused some employers to eliminate those benefits altogether. ${ }^{35}$ The number of large employers

24. See Hyman \& Hall, supra note 22, at 25 (arguing that unions were a factor in the rise in employee benefits); Cancelosi, supra note 22, at 88 (describing union negotiation efforts that led to an increase in employer-provided health benefits).

25. Cancelosi, supra note 22 , at 106.

26. 42 U.S.C. $\$ \$ 402(a)(3), 416(c)$ (2006).

27. Cancelosi, supra note 22 , at 97.

28. Id.

29. Id. at 108 .

30. Id. at 112-13 (citing a 2001 survey on Medicare beneficiaries with five or more chronic conditions).

31. See supra notes $6,10,16$ (citing employer survey and health care cost inflation data).

32. Rick Lindquist, Employer-Sponsored Health Insurance-Its Effect on Medical Expenses, ZANE BENEFITS BLOG (May 17, 2012, 10:09 AM), http://www.zanebenefits.com/blog/bid/143480/EmployerSponsored-Health-Insurance-Its-Effect-on-Medical-Expenses?utm_campaign=prweb-medical-expense\&utm _source=prweb.

33. Id. (noting that less than $50 \%$ of small employers offer health insurance).

34. See Paul Fronstin, EmP. Benefit Research INST., ISSUE BRief No. 338: IMPlications of HEALTH REFORM FOR RETIREE HEALTH BENEFITS 3-4 (2012), available at www.ebri.org/pdf/briefspdf/ EBRI_BB_01-2010_No338_Ret-hIth.pdf (explaining that many employers have limited access to health benefits for retirees); see also Ëllen E. Schultz, Facing Health-Plan Cuts, Wall ST. J., Apr. 20, 2012, http://online.wsj.com/article/SB10001424052702304331204577354294143782520.html (describing the rising costs for health insurance imposed on retirees); LARGE EMPLOYERS, supra note 6, at 3 (noting "top strategies" that employers use to control retiree health care costs include "capping company contributions (45\%), increasing employee contributions (31\%), and eliminating coverage for future retirees (28\%)").

35. See Bill Boies et al., Still Worthwhile? Weighing Retiree Drug Benefits Without a Subsidy Deduction, SOC'Y FOR HUM. RESOURCE MGMT. (July 29, 2010), http://www.shrm.org/hrdisciplines/benefits/Articles/Pages 
offering retiree benefits has fallen from $66 \%$ in 1988 , to $26 \%$ in $2011 . .^{36}$ In 2011 , only $24 \%$ of large firms ( 200 or more workers) offered retiree health benefits. ${ }^{37}$ Of those firms that do offer retiree health benefits, they are more likely to do so for early retirees not yet eligible for Medicare than for Medicare-eligible retirees. ${ }^{38}$ The RDS tax change, along with a number of other ACA provisions impacting employers, will likely accelerate the decline in employer-based retiree health plans. ${ }^{39}$

\section{B. Retiree Drug Subsidy}

With passage of the Medicare Prescription Drug, Improvement, and Modernization Act (MMA) of 2003,40 Congress, for the first time since Medicare's enactment in 1965 , added outpatient prescription drug coverage to the program. ${ }^{41}$ Previously, Medicare beneficiaries received prescription drugs, if at all, through other government programs, such as Medicaid, or, in some cases, from their previous employers. ${ }^{42}$ There was considerable concern that the creation of the Medicare "Part D" drug benefit would incentivize employers to "dump" their retirees into the new Medicare program, thereby decreasing their own health care costs and increasing the federal program's costs. ${ }^{43}$ President Bush vowed to keep the price tag for the new Part D to $\$ 400$ billion. ${ }^{44}$ To that end, the MMA included a $28 \%$ subsidy to employers that maintained, or began offering, Part D actuarially equivalent prescription drug benefit plans to their retirees. For participating employers, the $28 \%$ RDS was both non-includible as taxable income and deductible as a business expense. ${ }^{45}$ In effect, each dollar's worth of retiree drug benefits

/StillWorthwhile.aspx (explaining that some companies have eliminated retiree prescription drug benefits in light of increased costs).

36. Gary Claxton et al., Kaiser family found., Health Research \& Educ. Trust, Employer HEALTH BENEFITS: 2011 ANNUAL SURVEY 160-61 (Sept. 2011), available at http://ehbs.kff.org/pdf/ 2011/8225.pdf (noting that $91 \%$ of large firms that offer retiree health benefits cover early retirees-workers retiring before age $65-$ while only $71 \%$ offer health benefits to Medicare-age retirees).

37. Id. at 162 .

38. Id. at $164-65$.

39. See TOWERS WATSON \& INT'L SOC'Y OF CERTIFIED EMP. BENEFIT SPECIALISTS, REDEFINING RETIREE MEDICAL STRATEGY: EMPLOYER ACTIONS IN A POST-REFORM ENVIRONMENT 5 (2011), available at http://www.towerswatson.com/assets/pdf/4634/Towers-Watson-ICEBS-2011.pdf (noting that "[a]lmost 60\% of employers are rethinking their role in providing retiree medical or plan to do so in the next two years"); LARGE EMPLOYERS, supra note 6 , at 8 (reporting that $13 \%$ of surveyed employers currently receiving RDS subsidy plan to drop primary coverage for retirees in light of tax code change and other coverage options available to retirees).

40. 42 U.S.C. $\$ 1395(2006)$.

41. Id. $\$ 1395 \mathrm{w}-101$.

42. See Cancelosi, supra note 22, at 97 (describing the history of employer-provided health coverage); David Pratt, The New Medicare Part D Prescription Drug Benefit, 17 ALB. L.J. SCI. \& TECH. 337, 350-51 (2007) (noting other employer and government coverage).

43. Richard L. Kaplan, The Medicare Drug Benefit: A Prescription for Confusion, 1 NAT'L ACAD. ELDER L. ATT'Y J. 167, 178 (2005) (citing William G. Weissert, Medicare Rx: Just a Few of the Reasons Why It Was So Difficult to Pass, PUB. POL'Y \& AGING REP., Fall 2003, at 1, 1).

44. See Elizabeth A. Weeks, Cooperative Federalism and Healthcare Reform: The Medicare Part D "Clawback" Example, 1 ST. LouIS U. J. HEALTH L. \& POL'Y 79, 87 n.62 (2007) (noting President Bush's promise).

45. 42 U.S.C. $\S 1395 w-132$ (2006); 26 U.S.C. $\$ 139$ A (2006); see also Kaplan, supra note 43, at 179 (describing the operation of the federal subsidy); Cancelosi, supra note 22, at 122 (describing the provision's 
cost firms only $37 \notin$ after taxes. ${ }^{46}$

The RDS generally was quite successful in maintaining employer-provided retiree drug coverage. In 2006, the year that Part D took effect, $78 \%$ of employers planned to accept the federal RDS and provide drug coverage to their Medicare-eligible retirees. ${ }^{47}$ In fact, several employers threatened to drop retirees' other health benefits if they opted to enroll in Medicare Part D instead of employer plans. ${ }^{48}$ Employers did not want to provide health benefits without the benefit of the generous federal drug plan subsidy. Since 2006, the federal government has paid $\$ 14.6$ billion directly to employers through the RDS program. 49

The ACA retained the $28 \%$ RDS and its treatment as pre-tax dollars but repealed the deductibility of the RDS, effective 2013.50 Employers may still deduct the $72 \%$ contribution of their own funds that they make toward retiree drug plans but may no longer deduct the $28 \%$ received as a subsidy from the federal government. From the government's perspective, the change simply closed a loophole and prevented doubledipping by employers. ${ }^{51}$ From employers' perspectives, the very favorable tax treatment was a deliberate part of the MMA's anti-dumping design. ${ }^{52}$

By way of comparison, the ACA added another, even more generous, $80 \%$ federal subsidy for employers offering health insurance benefits to early retirees not yet eligible for Medicare. ${ }^{53}$ The $80 \%$ subsidy is available from 2010 to $2014,{ }^{54}$ when key health

aim to offset employers' incentives to reduce or eliminate prescription drug coverage); Pratt, supra note 42 , at $363-64$.

46. This calculation is based on $35 \%$ corporate income tax rate (e.g., $\$ 1.00(1-.35)-.28=.37)$. Corporate tax rate ranges from $15 \%$ for income below $\$ 50,000$ to $35 \%$ for income over $\$ 10$ million. 26 U.S.C. $\$ 11(\mathrm{~b})(1)$.

47. Frank MCARdle et al., Kaiser Family Found., HewitT AsSoc., Retiree Health Benefits EXAMINED: 2006 SURVEY ON RETIREE HEALTH BENEFITS 25 (Dec. 2006), available at http://www.kff.org/ medicare/upload/7587.pdf.

48. See Milt Freudenheim \& Robert Pear, New Medicare Plan Presents a Drug Benefit Conundrum, N.Y. TiMEs, Nov. 4, 2005, http://www.nytimes.com/2005/11/04/business/04retiree.html?pagewanted=print ("Many of those companies [offering drug insurance] have shown little interest in continuing to provide other, increasingly expensive health coverage to a retiree if they lose the drug subsidy.").

49. See Memorandum from U.S. House of Reps. Comm. on Energy \& Commerce to Chairmen Henry A. Waxman and Bart Stupak, Investigation of the Impact of the Health Care Reform Law on Large Employers 2 (Apr. 14, 2010) [hereinafter Committee Memo], available at http://democrats.energycommerce .house.gov/Press_111/20100414/memo.oi.2010.04.14.pdf. More than 3500 companies were receiving the RDS subsidy at the time the ACA was enacted. Funk, supra note 10.

50. 26 U.S.C. $\$ 139$ A.

51. See Kris Maher et al., Companies Take Health-Care Charges-Deere Joins Caterpillar, AK Steel in Toting Up Costs of Overhaul; White House Disputes Accounting, WALL ST. J., Mar. 26, 2010, http://online.wsj.com/article/SB10001424052748704094104575143723100528284.html (quoting White House Press Secretary Robert Gibbs, noting "[o]ur bill simply closes the loophole"); Timothy P. Carney, The Tangled Web of the Obamacare Write-Downs, WASH. EXAMINER, Apr. 2, 2010, http://washingtonexaminer.com/ article/32542 ("Democrats say the law closes a 'loophole' and the businesses [issuing SEC statements] are being disingenuous.").

52. See Letter from Fin. Execs. Int'l to Chairmen and Ranking Members of the Comm. on Energy and Commerce (Apr. 6, 2010), available at http://www.financialexecutives.org/eweb/upload/FEI/FEI\%20 Letter\%200n\%20Tax\%20Treatment\%20of\%20Medicare\%20Part\%20D_Final.pdf (describing MMA's favorable tax treatment for RDS as "clearly delineated policy"); Paul Howard, Obamacare's Hidden Costs, CITY J., May 13, 2010, http://www.city-journal.org/2010/eon0513ph.html (noting incentives built into RDS subsidy).

53. Patient Protection and Affordable Care Act (ACA), Pub. L. No. 111-148, § 1102, 124 Stat. 119, 143- 
insurance market reforms take effect. The ACA specifies that the early retiree reinsurance subsidy is excluded from the employer's gross income but is silent on deductibility. ${ }^{55}$ In the absence of an express declaration in the statute, some posit that the subsidy would be deductible. $^{56} \mathrm{~A}$ similar interpretation in the face of legislative silence supported the historical tax treatment for the RDS subsidy. 57

As originally enacted on March 23, 2010, the ACA's change in RDS tax treatment would have taken effect on December 31, 2010. Under the Reconciliation Act, signed by President Obama on March 30, 2010, the effective date for the RDS tax change was delayed until December 31, 2012. 58 Accordingly, until 2013, employers may continue to receive the RDS, exclude it from taxable income, and deduct the full cost of the retiree drug plan, including the $28 \%$ subsidy. ${ }^{59}$ The change effectively increases an employer's income tax liability and thereby, the cost of providing prescription drug coverage to retirees. ${ }^{60}$

\section{Post-ACA SEC Disclosures and Congressional Investigation}

Within a few days of Congress signing the ACA into law on March 23, 2010, several companies issued Form $8-\mathrm{K}$ statements, ${ }^{61}$ alerting the SEC and investors to significant non-cash charges against the companies' first-quarter earnings. In a few cases, the amounts reported were truly alarming. Large telecommunications companies were among the early filers. AT\&T reported a $\$ 1$ billion write-down, ${ }^{62}$ and Verizon reported $\$ 970$ million. ${ }^{63}$ Large manufacturers also reported significant impact. Caterpillar and Deere \& Co. reported $\$ 100$ million and $\$ 150$ million respectively. ${ }^{64}$ Our research identified a total of 147 firms that issued 8-Ks related to the RDS change, including ten firms that filed 8-Ks for the express purpose of reporting RDS-related write-offs, and another 40 that reported RDS write-offs as part of earnings releases filed in 8 -Ks

$45(2010)$ (codified as amended at 42 U.S.C. $\$ 18002(2012)$ ).

54. Id. $\S 1102(\mathrm{a})(1)$ (codified as amended at 42 U.S.C. $\S 18002(\mathrm{a})(1)(2012)$ ).

55. Id. $\$ 1102(\mathrm{c})(5)$ (codified as amended at 42 U.S.C. $\S 18002(\mathrm{c})(5)(2012)$ ).

56. See 26 U.S.C. $\S 162$ (2012) (regarding deductibility of trade or business expenses); see also Employers Should Prepare Immediately for Early Retiree Reinsurance Program Under PPACA, IVINS, PHILLIPS \& BARKER (May 10, 2010), http://www.ipbtax.com/newsletter-27.html (noting the need for IRS clarification).

57. See 29 U.S.C. $\$ 139$ A (2006); Employers Should Prepare Immediately, supra note 56 (interpreting same).

58. Health Care and Education Reconciliation Act of 2010, Pub. L. No. 111-152, 124 Stat. 1029 (codified as amended at 42 U.S.C. $\S 1305(2006))$.

59. ACA $\S 9012$, amended by IRC $\S 139$ A (effective date changed by $\S 1407$ of the Reconciliation Act).

60. See Boies et al., supra note 35 (explaining employers' tax liability will increase).

61. See Sarbanes-Oxley Act $\$ 409,15$ U.S.C. $\$ 78 \mathrm{~m}$ (2012) (requiring disclosure "on a rapid and current basis such additional information conceming material changes in the financial condition or operations of the issuer"); infra Part III.A.2 (describing Form 8-K requirements).

62. AT\&T, Current Report (Form 8-K) (Mar. 23, 2010), available at http://sec.gov/Archives/edgar/data/ 732717/000073271710000017/filing8k.htm.

63. Verizon, Current Report (Form 8-K) (Apr. 1, 2010), available at http://sec.gov/Archives/edgar/data/ 732712/000119312510075202/d8k.htm.

64. Caterpillar, Current Report (Form 8-K) (Mar. 2010), available at http://sec.gov/Archives/edgar/data/ 18230/000001823010000169/form8k_hr3590.htm; Deere \& Co., Current Report (Form 8-K) (Mar. 23, 2010), available at http://sec.gov/Archives/edgar/data/315189/000110465910016494/al0-7047_18k.htm. 
following the enactment of ACA and the Reconciliation Act.

Those high-dollar filings attracted the attention of U.S. Commerce Secretary Gary Locke and U.S. House of Representatives Henry Waxman and Bart Stupak. Secretary Locke accused the firms of being "premature and irresponsible" 65 in taking the writedowns and signaling "that the new health-care law is bad for business." 66 Representative Waxman charged the firms with "using the big numbers to exaggerate health care reform's burden on employers." 67

On March 26, 2010, Representatives Waxman and Stupak, Chairmen of the House Committee on Energy and Commerce, launched an investigation into firms' reported financial impact of ACA. The Committee sent letters to the four companies-AT\&T, Verizon, Caterpillar, and Deere \& Co.-reviewing supporting documentation and testimony from their CEOs. ${ }^{68}$ The Committee asserted that the 8-K write-offs appeared to conflict with independent analyses, which predicted that the ACA will expand coverage and bring down costs. ${ }^{69}$ The Committee also interviewed representatives of various trade organizations and interested parties, including the Business Roundtable, Financial Accounting Standards Board, health economists, and officials from the federal Centers on Medicare and Medicaid Services. ${ }^{70}$ The firms maintained that the filings were proper. A Caterpillar spokesman explained, "[w]e take a very prudent and cautious approach as it relates to all of our filings with the SEC and other regulatory agencies." the Committee's request, the firms produced hundreds of pages of documents relating to the write-down issue. ${ }^{72}$

On April 14, 2010, the Committee cancelled the hearing the day before it was scheduled, with the suggestion that "[t]here was consensus among the business executives" that the financial impact of the ACA could not be accurately assessed until fully implemented. ${ }^{73}$ Based on preliminary investigations, the Committee concluded that the companies' one-time charges were proper under Generally Accepted Accounting Principles (GAAP) and SEC rules, but perhaps still misleading. ${ }^{74}$

The Committee noted that the firms derived the large numbers reported in their 8-Ks in accordance with GAAP Financial Accounting Standard (FAS) 106, requiring

65. Robert Pear, Inquiry Says Health Care Charges Were Proper, N.Y. TIMES, Apr. 26, 2010, http://www.nytimes.com/2010/04/27/business/27health.html.

66. Maher et al., supra note 51.

67. Shawn Tully, Documents Reveal AT\&T, Verizon, Others, Thought About Dropping EmployerSponsored Benefits, CNNMONEY (May 6 2010, 11:52 AM), http://money.cnn.com/2010/05/05/news/ companies/dropping_benefits.fortune/.

68. See Committee Memo, supra note 49, at 1 (explaining the Committee's actions)

69. See id. at 4-5 (discussing outside opinion on the law and expressing a belief in a reduction in costs); Viola Gienger, AT\&T, Deere CEOs Called by Waxman to Back Up Health-Bill Costs, BLOOMBERG, Mar. 27, 2010, http://www.bloomberg.com/apps/news?pid=newsarchive\&sid=awoPw_Ty59og (discussing an estimate by Business Roundtable of reduced health-insurance cost trends).

70. Committee Memo, supra note 49, at 1 .

71. Maher et al., supra note 51.

72. Pear, supra note 65.

73. Committee Memo, supra note 49, at 5; David A. Hyman, Employment-Based Health Insurance: Is Health Reform a 'Game Changer?', in 2010 N.Y.U. REV. EMP. BENEFIT § IA.04 (2010) (accessible on Lexis Nexis).

74. Committee Memo, supra note 49 , at 3. 
employers to report retiree health benefits on an accrual rather than cash basis, ${ }^{75}$ and FAS 109 , which requires employers to recognize the estimated future tax effects resulting from a new tax law in the year of the law's enactment. ${ }^{76}$ Firms receiving the RDS had already "booked" the deferred tax benefit by recording an asset on their balance sheets, estimating the amount based on the number of years that the companies anticipated offering prescription drug benefits to their retirees. Some companies estimated to "infinity," while others had shorter horizons. ${ }^{77}$ When the ACA eliminated the deductibility of the subsidy, firms were required to write off the entire value of the related tax assets in the current year. ${ }^{78}$

Though proper, the Committee concluded that the firms' SEC filings could be "misconstrued" because the tax change will not take effect until 2013, and the filings did not reflect annual cash-flow impacts. ${ }^{79}$ Moreover, the Committee noted that several companies' documents and representatives suggested that, if implemented correctly, "the overall impact of the law on large employers could be beneficial." 80

The Energy and Commerce Committee Minority Staff separately reviewed the companies' documents and produced a memo concluding that the SEC filings were not only proper but had been forecast. ${ }^{81}$ The Minority Staff memo cited various documents from the companies and various trade groups, alerting Congress of the effects of the proposed RDS tax change and FAS rules that would require the write-offs. ${ }^{82}$ The Minority Staff's observations were not limited to the RDS issue. Its memo further noted that each of the five companies produced documents expressing concern about increased costs and long-term viability of providing not only retiree but also active employee benefits as a result of the ACA. ${ }^{83}$ The overall suggestion was that even if the $8-\mathrm{K}$ disclosures were auguring worse financial impacts on employers still to come, they were not inappropriate or unwarranted. ${ }^{84}$

75. EMPLOYERS' ACCOUNTING FOR POSTRETIREMENT BENEFITS OTHER THAN PENSIONS, Statement of Fin. Accounting Standards No. 106, $\$ 16$ (Fin. Accounting Standards Bd. 1990) [hereinafter FASB STATEMENT No. 106].

76. ACCOUnting For INCOME TAXES, Statement of Fin. Accounting Standards No. 109, 119 (Fin. Accounting Standards Bd. 1991) [hereinafter FASB STATEMENT No. 109].

77. Committee Memo, supra note 49, at 3.

78. See id: ASC 740-10-35-2 to 35-4 (regarding subsequent measurement of new information affecting tax positions and changes in laws or rates).

79. Committee Memo, supra note 49, at 3.

80. Id. at 2.

81. Internal Memorandum from the Comm. on Energy \& Commerce Minority Staff to Joe Barton \& Michael Burgess, on Investigation of AT\&T, Caterpillar, Deere \& Company, and Verizon By Majority 1 (Apr. 27, 2010) [hereinafter Minority Memo], available at health.burgess.house.gov/uploadedfiles/04-27-2010__minority_staff-memo_on_health_reform_and_businesses.pdf (explaining that the investigation was called off because the companies had done nothing wrong and complied).

82. See id. at 2 (explaining that the changes would expose companies to FAS 106 liability and disrupt the financial statements of those companies).

83. See id. at 3-4 (explaining that the legislation would increase $\$ 100$ million in the first year for Caterpillar alone and the pressure this would have on covering retired and current employees); see also Hyman, supra note 73, at 15-16 (noting that all four companies were "running the numbers" to decide whether to continue offering employee health benefits in light of the ACA).

84. See also Hyman, supra note 73 , at 16 (explaining that there are more factors than just money that make employers adopt the EBC). 


\section{SEC REQUIREMENTS AND ACCOUNTING STANDARDS}

This Part describes SEC disclosure requirements, including Form 8-K, and Financial Accounting Standards (FAS) applicable to the firms' RDS-related write-offs. As both the majority and minority members of the congressional committee concluded, the firms' filings were consistent with SEC and GAAP requirements. ${ }^{85}$ We note, however, these requirements allowed firms to signal objection to federal health reform through the novel speech venue of SEC filings. The RDS tax change, in particular, required rapid disclosure, current-year write-offs, and accrual-basis accounting, a confluence of factors that required, but also allowed, firms to report alarming reductions in their post-ACA earnings reports.

\section{A. SEC Disclosure Requirements}

Following the market crash in 1929, the federal government passed the Securities Act of 1933, which was "designed to provide investors with full disclosure of material information concerning public offerings of securities in commerce, to protect investors against fraud and, through the imposition of specified civil liabilities, to promote ethical standards of honesty and fair dealing." 86 The following year, Congress passed the Securities Exchange Act of 1934 (Exchange Act), ${ }^{87}$ imposing disclosure requirements on a continuous basis. The Securities Act Amendments of 1964 made them applicable to a much larger category of issuers. ${ }^{88}$ The goal of providing investors with current information on an ongoing basis is accomplished with periodic scheduled reports as well as current interim reports when triggered by certain material events.

\section{Scheduled Disclosure: Forms 10-K and 10-Q}

The two scheduled periodic reports under Sections 13 and 15(d) of the Exchange Act ${ }^{89}$ are the annual Form $10-\mathrm{K}^{90}$ and the quarterly Form $10-\mathrm{Q} .{ }^{91}$ Form $10-\mathrm{K}$ provides a comprehensive summary of a company's business and financial condition. Much of the information set forth in the annual report to shareholders ${ }^{92}$ and Form $10-\mathrm{K}$ overlap, but the two reports are distinct. ${ }^{93}$ Form $10-\mathrm{Q}$ is the quarterly report that firms are required to

85. See Boies et al., supra note 35 ("Although employers will not face the higher tax liability until 2013, under financial accounting rules employers must now include the present value of the future taxes as a current liability charged against earnings.").

86. Ernst \& Ernst v. Hochfelder, 425 U.S. 185, 195 (1976) (citing H.R. REP. No. 85-73, at 1-5 (1933)).

87. Securities Exchange Act of 1934, Pub. L. No. 73-291, 48 Stat. 881 (codified at 15 U.S.C. § 78a-pp).

88. See generally Lee J. Sclar, The Securities Acts Amendments of 1964: Selected Provisions and Legislative Deficiencies, 53 CALIF. L. REV. 1494 (1965) (showing how the Security Act Amendments of 1964 expanded federal regulation based on 30 years of experience).

89. 15 U.S.C. $\$ \S 78 \mathrm{~m}, 780(\mathrm{~d})(2012)$.

90. Id. $\$ 249.310$.

91. Id. $\S 249.308 \mathrm{a}$.

92. 17 C.F.R. $\$ 240.14 a-3$ (2012).

93. Because Form 10-K encompasses the disclosure requirements for the annual report to shareholders in greater detail, most companies use their Form $10-\mathrm{K}$ as their annual report to shareholders. Accordingly, the 10 $\mathrm{K}$ filed with the SEC and the annual report provided to shareholders are usually identical. OFFICE OF INVESTOR EDUC. \& ADVOCACY, SEC, SEC INVESTOR BULLETIN: HOW TO READ A 10-K, at 1 (Sept. 2011), available at www.sec.gov/investor/pubs/reada10k.pdf. Form $10-\mathrm{K}$ is broken down into four parts: Part I includes 
file for the first three quarters of the fiscal year. ${ }^{94}$ The $10-\mathrm{Q}$ provides unaudited financial statements as well as "a continuing view of the company's financial position during the year."95

Prior to the 2002 and 2004 adoption of the accelerated filer distinction ${ }^{96}$ and large accelerated filer distinction, ${ }^{97}$ respectively, issuers were required to file Form $10-\mathrm{K}$ within 90 days after the end of the fiscal year, and Form 10-Q within 45 days after the end of the quarter for the first three quarters. The deadlines for filing now range from 60 to 90 days for the $10-\mathrm{K}$, and 40 to 45 days for the $10-\mathrm{Q}$, depending on whether the firm designates an issuer as an accelerated filer, ${ }^{98}$ large accelerated filer, ${ }^{99}$ or non-accelerated filer. ${ }^{100}$

\section{Current Reports: Form $8-K$}

Certain information, triggered by various events in the interim between Forms $10-\mathrm{K}$ and 10-Q filings, must be disclosed on Form 8-K. ${ }^{101}$ Form 8-K is used to report "extraordinary" corporate events, such as bankruptcy, acquisition or disposition of significant assets, change in fiscal year, or change in control of the company. There are 27 mandatory disclosure items, ${ }^{102}$ including registrant's business and operations, financial information, securities and trading markets, matters relating to accountants and financial statements, corporate governance and management, asset-backed securities, regulation fair disclosure (FD), financial statements and exhibits for businesses acquired, pro forma financial information, and shell company transactions. ${ }^{103}$ All mandatory

information regarding the firm's business, risk factors, properties, and legal proceedings. Id. Part II provides audited financial statements, the management's discussion and analysis, quantitative and qualitative disclosures about market risk, and income and balance sheet data. Id. Part III incorporates information regarding the company's directors, officers, and corporate governance as well as principal fees and services. Id. Part IV contains schedules to the financial statements as well as various exhibits. Id.

94. 17 C.F.R. $\$ 249.308 \mathrm{a}(\mathrm{a})$.

95. Form 10-Q is broken down into two parts: Part I provides financial information including financial statements, management's discussion and analysis of financial condition and results of operations, quantitative and qualitative disclosures about market risk, and controls and procedures. Form 10-Q, U.S. SEC. \& EXCHANGE COMMISSION, http://www.sec.gov/answers/form10q.htm (last modified Sept. 2, 2011). Part II includes other information such as legal proceedings and risk factors. Id.

96. Acceleration of Periodic Report Filing Dates and Disclosure Concerning Website Access to Reports, Securities Act Release No. 33,8128, Exchange Act Release No. 34,46464, 78 SEC Docket 1015, 78 SEC Docket 1139 (Sept. 5, 2002).

97. Revisions to Accelerated Filer Definition and Accelerated Deadlines for Filing Periodic Reports, Securities Act Release No. 33,8644, Exchange Act Release No. 34,52989, 86 SEC Docket 2355 (Dec. 27, 2005).

98. See 17 C.F.R. $\$ 240.12 b-2$ (1) (defining accelerated filer).

99. See 17 C.F.R. $\$ 240.12 b-2$ (2) (defining large accelerated filer).

100. Revisions to the Accelerated Filer Definition, supra note 97, at 25 (providing chart depicting three tiers of filings deadlines for $10-\mathrm{K}$ and $10-\mathrm{Q})$.

101. 15 U.S.C. $\$ 78 \mathrm{~m} \mathrm{(2012);} 17$ C.F.R. $\$ 240.13 \mathrm{a}-11$.

102. In 2004, the SEC expanded and renumbered Form $8-\mathrm{K}$ items. Of specific importance, "the Form $8-\mathrm{K}$ item permitting voluntary disclosure of 'other events' that was formerly designated as Item 5 now appears as Item 8.01." Additional Form 8-K Disclosure Requirements and Acceleration of Filing Date, Securities Act Release No. 33,8400, Exchange Act Release No. 34,49424, 82 SEC Docket 1480 (Mar. 16, 2004).

103. Form 8-K, General Instructions, U.S. SEC. \& EXCHANGE COMMISSION 4-22, www.sec.gov/about/ forms/form8-k.pdf (last visited Jan. 5, 2013). 
disclosure items (except regulation FD) must be filed within four days of the triggering event. ${ }^{104}$ In response to corporate scandals, such as Enron, congressional and SEC policies emphasize more rapid and expansive disclosure of information regarding public companies' financial conditions and operations. ${ }^{105}$

The trigger for 8-K reporting is "materiality," specifically, "information concerning material changes in the financial condition or operations of the issuer." 106 SEC guidance cautions companies against relying on "rules of thumb," such as a five percent threshold, for determining materiality. Rather, the standard is nuanced and requires judgment. "A matter is 'material' if there is a substantial likelihood that a reasonable person would consider it important." 107 In defining materiality, the SEC relies on the U.S. Supreme Court's holding in TSC Industries, Inc. v. Northway, Inc. that facts are "material" when there is a "substantial likelihood that a reasonable shareholder would consider it important in deciding how to vote." 108 Further, if a reasonable investor would view the fact as having significantly altered the "total mix" of available information, the fact is considered material. 109 The SEC specifies "that financial management and the auditor must consider both 'quantitative' and 'qualitative' factors in assessing an item's materiality," and affirms that "[c]ourt decisions, Commission rules and enforcement actions, and accounting and auditing literature have all considered 'qualitative' factors" 110 bearing on materiality.

In addition, the Exchange Act, as amended by the Private Securities Litigation Reform Act of 1995, ${ }^{111}$ provides a safe harbor for forward-looking statements, defined as "a statement containing a projection of revenues, income (including income loss), earnings (including earnings loss) per share, capital expenditures, dividends, capital structure, or other financial items." The forward-looking safe harbor, which several firms in our study cited in their disclosure statements, ${ }^{112}$ shields firms from investor liability

104. Id. at 2. Regulation FD disclosure timing is dictated by 17 C.F.R. $\S 243.100$, which provides that when material nonpublic information is disclosed to certain persons it must be disclosed to the public simultaneously when it is intentionally disclosed and promptly when unintentionally disclosed. See generally Page \& Yang, supra note 7 (considering First Amendment implications of regulation FD).

105. See Jennifer B. Lawrence \& Jackson W. Prentice, The SEC Form 8-K: Full Disclosure or Fully Diluted? The Quest for Improved Financial Market Transparency, 41 WAKE FOREST L. REV. 913, 915-17 (2006) (describing context for enactment of Sarbanes-Oxley Act of 2002 and Form 8-K amendments); E. Richie Reyes, Can America Escape the Cloud of Corporate Corruption with the Sarbanes-Oxley Act of 2002? A Proposal to Restore Efficiency and Integrity into the Capital Markets by Mandating Corporate Disclosures of Real-Time Information and Encouraging Investor Education, 24 HAMLINE J. PUB. L. \& POL'Y 147, 168 (2002) (describing policymakers' goals of restoring market efficiency and investor confidence, post-Enron); Wally Suphap, Getting It Right Versus Getting It Quick: The Quality-Timeliness Tradeoff in Corporate Disclosure, 2003 COLUM. BUS. L. REV. 661, 662-75 (2003) (analyzing changes to disclosure requirements following Sarbanes-Oxley).

106. Sarbanes-Oxley Act, Pub. L. No. 107-204, § 409, 116 Stat. 791(2002) (codified as amended at 15 U.S.C. $\$ 78 \mathrm{~m}(1)(2006))$.

107. SEC Staff Accounting Bulletin No. 99, 64 Fed. Reg. 45150-01, 1999 WL 625156, at *3 (Aug. 19, 1999) [hereinafter Bulletin No. 99], available at http://www.sec.gov/interps/account/sab $99 . \mathrm{htm}$.

108. TSC Indust., Inc. v. Northway, Inc., 426 U.S. 438, 449 (1976).

109. Id; see Bulletin No. 99, supra note 107 (citing cases).

110. Bulletin No. 99, supra note 107.

111. 15 U.S.C. $\$ 78 \mathrm{u}-5(\mathrm{i})(1)(\mathrm{A})(2012)$.

112. See, e.g., AT\&T, supra note 62; Verizon, supra note 63; Caterpillar, supra note 64 (referencing forward-looking statements). 
for material misstatements about expected future events and financial results that are subject to risks and uncertainties.

\section{B. Generally Accepted Accounting Principles}

Two financial accounting standards are relevant to the financial reporting after ACA: FAS 106, accounting for postretirement benefits, and FAS 109, accounting for income taxes. These standards are now codified in the Financial Accounting Standards Board's Accounting Standards Codification (ASC) in ASC 715-60, CompensationRetirement Benefits-Defined Benefit Plans-Other Postretirement and ASC 740Income Taxes, respectively. ${ }^{113}$

When FAS 106 was first issued, it effected a significant change in employers' accounting for postretirement benefits other than pensions. Until the early 1990s, employers accounted for postretirement benefit expenses, including retiree drug plans, on a cash or pay-as-you-go basis, meaning that the costs of those benefits were not reported as expenses until they were actually paid out to retirees. ${ }^{114}$ FAS 106 instead required accrual-basis accounting, even for deferred benefits. Accrual-basis accounting "attempts to recognize the events of noncash transactions and events as they occur." 115 Accordingly, employers must recognize the expected cost of future benefits for employees and their beneficiaries and dependents during the years in which each employee renders the services necessary to earn the postretirement benefits. Thus, when FAS 106 was issued, firms recorded large liabilities for their future benefit payments and began reporting current expenses for future payments of postretirement benefits. After this change in accounting treatment, there was a significant drop in the percentage of companies offering retirement benefits. ${ }^{116}$ These requirements are now codified in ASC 715-60.

Second, ASC 740 (initially issued as FAS 109) governs the reporting of tax positions for financial statement purposes. When differences arise between the tax and accounting treatments for a transaction (book-tax difference), ASC 740 requires firms to record the value of these differences as deferred tax assets or liabilities. For example, firms with net operating losses (NOLs) may use these NOLs to offset future taxable income. This book-tax difference creates a deferred tax asset because a future tax payment is lower due to the anticipated use of the NOL. Conversely, deferred tax liabilities are created when book-tax differences give rise to future tax liabilities. Because

113. ACCOUNTING STANDARDS CODIFICATION (Fin. Accounting Standards Bd.), available at http://asc.fasb.org/; see also Commission Guidance Regarding the Financial Accounting Standard Board's Accounting Standards Codification, 74 Fed. Reg. 42,772, 42,772 (Aug. 25, 2009) (to be codified at 17 C.F.R. pts. 211, 231, 241) (noting that the SEC FASB Accounting Standards Codification is generally accepted for purposes of the federal securities laws).

114. Summary of Statement No. 106: Employers' Accounting for Postretirement Benefits Other Than Pensions, FIN. ACCT. STANDARDS BOARD, http://www.fasb.org/summary/ stsuml06.shtml (last visited Jan. 5, 2013).

115. Id.; see also FRONSTIN, supra note 34 (discussing accounting treatment); Cancelosi, supra note 22, at 104 (discussing how FAS 106 may have caused retirement health insurance to skyrocket, thus causing many employers to cut back on providing health insurance for retirees).

116. See FrONSTIN, supra note 34 (describing how FAS 106 made companies aware of the long-term liability of offering retiree health benefits, and as a result, companies began overhauling their retiree health programs). 
deferred tax assets and liabilities are based upon future tax values, ASC 740 also requires firms to update the deferred tax asset and liability amounts when tax rates or tax laws change. ${ }^{117}$ Accordingly, firms are required to take a noncash charge against current earnings, reflecting the value of the loss of future tax deductions. ${ }^{118}$

ASC 740 does not employ discounting for the time-value of money, which may result in larger present-day write-offs. For example, a deferred tax asset available in $\mathbf{4 0}$ years has a relatively small present value in economic terms, but the financial statement reflects the value as if the benefit or liability were due in the current period. That accounting makes for a larger balance than would occur if discounting factors were applied (as in other accounting treatments for pensions and debt). When the tax benefits were provided through the MMA in 2003, firms recognized a deferred tax asset for the future tax benefits. Upon enactment of ACA in 2010, these same firms were required to reverse the entry and eliminate the deferred tax asset for the amount of benefit previously recorded.

\section{EMPIRICAL METHODOLOGY}

This study examined the proposition that firms' SEC disclosures reporting the effects of the RDS tax change in the ACA were politically motivated. Our analysis confirms and amplifies the House Committee's conclusions, demonstrating with a more comprehensive dataset that employers' post-ACA disclosures were both required and proper. The disclosures may have had a double-effect of carrying a political message, but that does not undermine their accuracy.

We derived our sample by cataloguing employers' $8-\mathrm{K}, 10-\mathrm{Q}$, and $10-\mathrm{K}$ statements reporting financial impact due to the RDS tax change for the quarter after ACA's enactment. We then analyzed the data in terms of disclosure venue, narrative statements on the disclosures, disclosure amount, industry type, firm size, and lobbying history to reveal any patterns suggesting purely political motivation. We also examined market response to the disclosures. SEC filings are mandatory for firms whose financial results are materially impacted by any event, making it difficult to isolate political motivation as a factor. We note, however, that the unique reportability of the RDS tax change allowed firms a rare opportunity to make a political statement through SEC disclosures. The government's attempt to suppress this and similar corporate speech could undermine the availability and reliability of such disclosures.

\section{A. Sample Identification}

To identify our sample, we searched the LexisNexis SEC Filings Library, 8-K, 10$\mathrm{Q}$, and 10-K Files for the period beginning March 15, 2010, through July 31, 2010. This period begins a week prior to passage of the ACA, in case any companies disclosed

117. Summary of Statement No. 109: Accounting for Income Taxes, FIN. ACCT. STANDARDS BOARD, http://fasb.org/summary/stsum109.shtml (last visited Jan. 5, 2013).

118. See Financial Reporting Alert 10-3 (Revised) Health Care Legislation Eliminates Tax Deduction Related to Medicare Part D Subsidy, DELOITTE (Mar. 31, 2010), http://www.deloitte.com/view/en_US/ us/Services/audit-enterprise-risk-services/Financial-Statement-Intemal-Control-Audit/Accounting-StandardsCommunications/b9500b1044c97210VgnVCM100000ba42f00aRCRD.htm [hereinafter Deloitte Part D Subsidy Alert]. 
possible write-offs prior to enactment, but we did not identify any early disclosures. We searched through the end of July 2010 to capture the last quarter-end date that would include March 23 events. 10-Qs are due 40 to 45 days after quarter end; therefore, a March to May fiscal quarter would be filed at or near the end of July 2010. A January to March fiscal quarter would be filed earlier.

Our primary search terms were " "plan d' within 5 words of 'subsidy' and 'medicare." We tested several additional terms including "retiree," "hr 3590," "affordable care act," "tax treatment part d," "retiree drug subsidy," and "patient protection." These searches returned fewer relevant documents and no additional companies.

Our searches identified 203 companies that specifically mentioned the RDS provision of the ACA. Of these, 19 mentioned elimination of the Part D subsidy only to state that it did not affect the company, usually because the company did not provide qualifying benefits or receive the subsidy. 119 Thirteen companies reported that elimination of the subsidy was immaterial to their financial results. ${ }^{120}$ Another 16 companies appear to have received the subsidy but did not provide an amount or any indication of why they failed to provide an amount. ${ }^{121}$ We presumed these amounts were

119. For example, Eastman Kodak's March 31, 2010, 10-Q stated:

In March 2010, the Patient Protection and Affordable Care Act and the Health Care and Education Reconciliation Act of 2010 were signed into law in the United States. This legislation extends health care coverage to many uninsured individuals and expands coverage to those already insured. The Company is continuing to assess the potential impacts that this legislation may have on future results of operations, cash flows or financial position related to our health care benefits and postretirement health care obligations. One provision that will impact certain companies significantly is the change in the tax deductibility of the Medicare Part D subsidy available from the U.S. Government to companies that provide qualifying prescription drug coverage to retirees. This provision does not impact the Company as it does not receive this subsidy.

Eastman Kodak Co., Quarterly Report (Form 10-Q) 25 (Mar. 31, 2010) (emphasis added), available at http://www.faqs.org/sec-filings/100429/EASTMAN-KODAK-CO_10-Q/.

120. For example, UPS's June 30, 2010, 10-Q stated:

The enactment of the "Patient Protection and Affordable Care Act" and "The Health Care and Education Reconciliation Act of 2010" in 2010 will bring significant changes to the U.S. health care system. The legislation eliminated the tax deductibility of Medicare Part $D$ subsidies for retiree prescription drug coverage; however, this impact was not material to our financial results. We are evaluating the long-term impacts of this legislation to us. It is difficult to estimate the impact due to the nature of our workforce, the various years in which certain provisions become applicable, and the fact that additional regulatory and rule setting guidance will be occurring. Our initial estimate is that we will incur an additional $\$ 50$ to $\$ 65$ million of annual expense beginning in 2011 , which is primarily due to the multiple coverage provisions of the legislation which require the expansion of dependent coverage to age 26 , among other requirements.

United Parcel Service, Inc., Quarterly Report (Form 10-Q) 11, 45 (June 30, 2010) (emphasis added), available at $\mathrm{http}: / /$ markets.deseretnews.com/deseretnews/action/getedgarwindow?accesscode=119312510182606.

121. For example, Todd Shipyard's March 31, 2010, 10-Q pension footnote reported:

We sponsor a post retirement health care benefit plan that provides prescription drug benefits that are deemed actuarially equivalent to Medicare Part D. ... The Patient Protection and Affordable Care Act, which was signed into law in March 2010, will result in our Medicare Part D subsidy becoming taxable in 2013 .

Todd Shipyards Corp., Quarterly Report (Form 10-Q) n.8 (July 4, 2010), available at 
typically small or immaterial. Seven companies reported a write-off, but not the amount written off because the accounting for the write-off did not affect net income. ${ }^{122}$ Finally, one company reporting a small write-off $(\$ 100,000)$ was not in the Compustat database from which we drew supporting financial information and, accordingly, was eliminated from further consideration. ${ }^{123}$ In sum, our analysis consists of 147 unique companies reporting the specific dollar effect of the elimination of deductibility of the Part D RDS subsidy. 124

Table 1: Companies Analyzed

Companies mentioning ACA Medicare Part D subsidy

Part D elimination did not affect company

Part D write-off immaterial

Write-off presumed immaterial

Write-off against allowance-amount not reported

Company not in Compustat database

Companies analyzed

http://www.sec.gov/Archives/edgar/data/98537/000009853710000027/form10qfyl lq1.htm.

122. This can happen for two reasons. First, some companies offset the elimination of the tax asset against a previously recorded allowance account rather than recording a current tax expense. That is, they already expected they would not benefit from the tax asset, typically because they did not expect to have sufficient future income. For example, Owens Corning's tax footnote in its March 31, 2010, 10-Q reported:

During the first quarter of 2010 , comprehensive health care reform legislation under the Patient Protection and Affordable Care Act (HR 3590) became law. Included among the major provisions of the law was the elimination of the deduction for the Medicare Part D subsidy. Due to the Company's valuation allowance against its United States deferred tax assets, there was no impact to the Company's financial results related to this legislation.

Owens Corning, Quarterly Report (Form 10-Q) 22, 32 (Mar. 31, 2010) (emphasis added), available at http://www.sec.gov/Archives/edgar/data/1370946/000119312510095732/d10q.htm (referring to "financial results" as earnings in this context). The second reason earnings may be unaffected is because some utility companies are allowed to pass these additional taxes onto rate payers. In this case, when the tax asset is written off, the company records a "regulatory asset," essentially a receivable from future rate payers, rather than an expense. When companies in these situations did report the amount of the write-off, we retained them in our sample because future cash flows will be the same regardless of whether the write-offs reduced current earnings. For example, Westmoreland Coal wrote off a \$7.2 million asset, and Media General wrote off a \$1.7 million asset against valuation allowances. Both are included in our analysis.

123. See AMH Holdings, LLC (Form 10-Q) 9 (August 11, 2010), available at http://sec.gov/Archives/ edgar/data/1289559/000095012310076101/c04649el0vq.htm.

124. In identifying unique companies, we were careful to include only parent companies, and not both parents and subsidiaries reporting separately. A parent company's consolidated financial statements include its subsidiaries' results; therefore, including both would double count subsidiary write-offs. We were particularly careful to identify the correct reporting entity for utility companies, which often have complicated corporate structures. 


\section{B. Disclosure Venue}

To examine the proposition that the firms' SEC disclosures were politically motivated, we compared firms that disclosed write-offs on Form 8-K very soon after the ACA was enacted with firms that waited to report the write-off in scheduled SEC quarterly and annual reports. Our study revealed that 15 companies issued Form 8-Ks solely to report large write-offs, and an additional 50 companies discussed the write-offs on Form 8-Ks in the context of quarterly earnings reports.

We anticipated that Form 8-K disclosures would operate as political speech venues more obviously than scheduled $10-\mathrm{Q}$ and $10-\mathrm{K}$ disclosures because of the rapid disclosure requirement and flexible materiality standard. The $8-\mathrm{K}$ timeframe required firms to report the RDS tax changes the firm deemed material within four days of the President's signing of the ACA, on March 23, 2010, or the Reconciliation Act, on March 30,2010 , when the political debate over federal health reform was still very fresh in the public's mind. Moreover, fluidity in the materiality standard accords firms discretion regarding whether and how much of a financial impact to report. Firms could exercise greater discretion to report arguably non-material impacts (e.g., not within a five percent change in assets).

Of the 147 write-offs, 82 (56\% of our sample) were reported in scheduled SEC periodic filings: Form $10-\mathrm{K}$ annual reports or Form 10-Q quarterly reports. Most of these firms reported the write-off in their discussion of tax expenses. The other 65 firms $(44 \%$ of our sample) reported the write-off on Form 8-K. Firms filed some of these Form 8-Ks specifically to announce the RDS-related write-off, but most firms disclosed Form 8-K write-offs in the context of quarterly earnings announcements or, in a few cases, other corporate disclosures. Within this group, some earnings announcements featured the write-off prominently, such as in the headline or first paragraph. In others, the firm discussed the write-off deeper in the text of the release. The table below provides the distribution of the disclosure venues and the write-off amounts associated with each category.

\section{Table 2: Disclosure Venues}

\begin{tabular}{|c|c|c|c|c|}
\hline \multirow[b]{2}{*}{ Types of Form 8-K disclosures: } & \multicolumn{4}{|c|}{ Write-off amount (\$M) } \\
\hline & $\underline{\text { Firms }}$ & $\underline{\text { Average }}$ & $\underline{\text { Median }}$ & $\underline{\text { Sum }}$ \\
\hline Write-off is purpose of $8-K$ & 15 & 175.4 & 75.0 & 2631.7 \\
\hline $\begin{array}{l}\text { Earnings release- } \\
\text { write-off is prominent }\end{array}$ & 18 & 31.5 & 10.2 & 566.4 \\
\hline $\begin{array}{l}\text { Earnings release- } \\
\text { write-off not prominent }\end{array}$ & 32 & 17.9 & 11.9 & 572.3 \\
\hline All Form 8-K disclosures & 65 & 58.0 & 17.0 & 3770.4 \\
\hline Scheduled periodic filings & 82 & 15.4 & 5.3 & 1269.1 \\
\hline Sample total & 147 & 34.3 & 7.1 & 5039.4 \\
\hline
\end{tabular}

In our sample, companies filing 8-Ks, as opposed to scheduled periodic filings, reported significantly higher write-offs. 8 -K filers accounted for three-quarters (or about 
$\$ 3.8$ billion) of the total $\$ 5$ billion written off. Although more companies reported RDS write-offs in scheduled financial reports, the total amount those companies wrote off was less than half of the total reported in Form 8-Ks. In addition, the average write-off by $8-\mathrm{K}$ filers was much higher ( $\$ 58$ million) compared to an average of $\$ 15.4$ million by $10-\mathrm{Q}$ and $10-\mathrm{K}$ filers.

The companies that issued real-time disclosures expressly for the purpose of announcing the RDS impacts wrote off the highest dollar amounts by any measure. Among the 65 companies filing $8-\mathrm{Ks}, 15$ issued the disclosures expressly to report the RDS write-off. These 15 companies wrote off the highest total, average, and median amounts. Indeed, these 15 companies alone wrote off over half of the total dollars for our entire sample of 147 companies ( $\$ 2.6$ billion of $\$ 5$ billion total). Average write-offs for these companies were $\$ 175.4$ million.

Eighteen additional companies reported the RDS on Form 8-Ks, among other corporate news (typically quarterly earnings results), and prominently featured the RDS tax change in the disclosure narrative. The companies that highlighted the RDS also wrote off relatively higher amounts than the remaining companies in our study. These companies wrote off an average of $\$ 31.5$ million each, compared to an average of $\$ 17.9$ million for the 32 additional $8-\mathrm{K}$ filers that did not note the RDS prominently.

Finally, the write-off amounts disclosed in scheduled $10-\mathrm{K}$ and $10-\mathrm{Q}$ filings were smaller than the amounts reported in any Form 8-K filing group. The differences across these four disclosure groups are statistically significant (Analysis of Variance (ANOVA) p-value $<0.01$ ).

This write-off pattern is consistent with companies' claims that they properly used Form 8-K to disclose "material" write-offs likely to be significant to shareholders. The pattern is also consistent with our expectation that $8-\mathrm{K}$ filers may have had stronger political motivation than scheduled filers. Firms experiencing a larger financial impact as a result of the RDS tax change, specifically, and the ACA's enactment, generally, may have seized the Form $8-\mathrm{K}$ as a unique speech venue to immediately signal their political objection to the ACA and to express concern over the impact of the new law on their finances and their employee benefits programs.

Possible support for the political motivation of 8-K filers is revealed through further analysis of these data. Interestingly, when we scaled the write-off amounts by the companies' assets or revenues, the statistically significant differences across disclosure groups disappeared. Regardless of the venue in which the write-offs were disclosed, the amounts represented, on average, $.2 \%$ to $.3 \%$ of firms' total assets, and $.3 \%$ to $.4 \%$ of revenues. ${ }^{125}$ Although the higher end of these ranges correspond to companies issuing Form $8-\mathrm{Ks}$, the differences are not statistically significant. Similarly, write-offs were less than $.001 \%$ of market capitalization for all groups. Materiality is a relative concept; therefore, based on these comparisons, one could argue that the write-offs were not relatively more material for companies filing Form $8-\mathrm{Ks}$, despite the differences in absolute amounts. In other words, the 65 companies that issued Form 8-Ks may have seized upon the discretion to deem the change in tax treatment for the RDS "material" in

125. We use 2009 financial results as a basis for comparison because, for most companies, the write-offs affected the first quarter of 2010 . Thus, balances at the end of 2009 were the most recently reported annual results at the companies that disclosed the write-offs. 
order to make a political statement in the immediate wake of the ACA's enactment.

Setting aside for now the question whether the impact of the RDS change was more or less material for some firms in our sample, the amounts written off overall represented a considerable proportion of all of the companies' 2009 net income or loss. Separating companies with profitable and unprofitable years, and excluding one outlier, ${ }^{126}$ the amounts written off represented about $6 \%$ of the prior year's net income, and, for companies reporting losses, nearly $11 \%$ of the loss. Companies were significantly more likely to feature the write-off prominently in their earnings releases when the amount was a larger proportion of the prior year's loss but not if it was a larger proportion of income.

\section{Table 3: Write-off as a Percent of Income or Loss}

\begin{tabular}{|c|c|c|c|c|}
\hline & Firms & Income & $\underline{\text { Firms }}$ & $\underline{\text { Loss }}$ \\
\hline \multicolumn{5}{|l|}{ Type of Form 8-K disclosure: } \\
\hline Write-off is purpose of 8-K & 12 & $10.8 \%$ & 3 & $-2.5 \%$ \\
\hline $\begin{array}{l}\text { Earnings release- } \\
\text { write-off prominent }\end{array}$ & 16 & $7.0 \%$ & 2 & $-58.9 \%$ \\
\hline $\begin{array}{l}\text { Earnings release- } \\
\text { write-off not prominent }\end{array}$ & 26 & $5.5 \%$ & 6 & $-8.9 \%$ \\
\hline Scheduled periodic filings & 66 & $5.8 \%$ & 15 & $-6.9 \%$ \\
\hline & 120 & $6.4 \%$ & 26 & $-10.9 \%$ \\
\hline
\end{tabular}

Overall, it appears that the absolute, but not the relative, amount of write-offs affected the choice of disclosure venue, and companies disclosing on Form 8-K have significantly larger write-offs than those that did not.

\section{Company Demographics}

We also studied whether the incidence of RDS write-offs correlated with certain industries or firm size to identify possible patterns of political motivation. We found that write-offs were concentrated in the telecommunications, manufacturing, and utilities industries and among larger companies with more employees. These results are consistent with historical patterns of industry types and firm sizes offering retiree health insurance benefits. Such employers are likely both to experience more material financial impacts as a result of the RDS tax change and to have greater political interest in federal regulation of retiree benefits.

\section{Industry}

Considering the distribution of firms in our sample across industries, telecommunication companies wrote off the largest share of the total $\$ 5$ billion: $\$ 2.2$ billion (43\%). A close second was the manufacturing industry, with $\$ 1.9$ billion (38\%).

126. For the loss analysis, we excluded Gaylord Entertainment. It wrote off $\$ 800,000$, more than 34 times the net loss of $\$ 23,000$ it reported in 2009 , per Compustat. Gaylord disclosed the write-off in a scheduled quarterly report. See Gaylord Entertainment (Form 10-Q) n.12 (May 6, 2011), available at http://sec.gov/ Archives/edgar/data/1040829/000095012310046457/g23246el 10vq.htm. 
Utilities companies were a distant third, writing off $\$ 0.5$ billion $(9 \%) .{ }^{127}$ Furthermore, in each of these industries, the proportion of companies reporting write-offs was statistically higher than would be expected if the write-offs were randomly distributed. ${ }^{128}$ We were not especially surprised by those findings. All three industries include highly unionized companies. Unionized industries are both more likely to offer retiree health benefits and less able to reduce or offset the costs of those benefits due to long-term union contracts. ${ }^{129}$ Our data roughly correlate with employer health benefits survey data indicating that $19 \%$ of manufacturing firms, 30\% of agriculture, mining, and construction firms, and $47 \%$ of transportation, communication, and utilities firms offer retiree health benefits. ${ }^{130}$ Only four percent of the dollars written off in our sample were attributed to finance firms, a somewhat surprising finding given that the employer benefits survey found that $42 \%$ of finance firms (the second largest group, exceeded only by public sector employers) offer retiree benefits. ${ }^{131}$

127. The telecommunication industry is defined as companies in SIC codes 4800-99. Manufacturing companies are in SIC codes 2000-3999 and utility companies are in SIC codes 4600-799 and 4900-99. Standard Industrial Classification Manual 1987 (incorporated by reference into Federal Register by 5 U.S.C. $\S$ 552(a) (2009)).

128. This result is based on Chi-square analysis of the proportion of companies in each industry reporting write-offs. For comparison, the analysis uses 2436 companies with SIC codes available in Compustat. The level of confidence (p-value of the Chi-square statistic) is better than .01 .

129. See Neil King, Firms Warn of Cuts to Benefits, WALL ST. J., Dec. 24, 2009, http://online.wsj.com/ article/SB126161924096903617.html (suggesting that companies likely to be hardest hit by RDS tax change "are unionized and offer better retiree benefits than are available under Medicare"); Maher et al., supra note 51 (noting that the RDS change "is expected to affect primarily industrial companies with retirees represented by collective bargaining pacts, whose benefits are more difficult for companies to cut"); CLAXTON ET AL., supra note 36, at 163 (noting characteristics of large employers offering retiree health benefits, including union workers, older workers, full-time workers, and higher wage level).

130. CLAXTON ET AL., supra note 36, at 162 (showing data on firms offering health benefits to active workers, and the percentage of firms offering retiree health benefits, by industry).

131. Id. 
Table 4: Write-offs by Industry

\begin{tabular}{|c|c|c|c|c|}
\hline SIC code ${ }^{132}$ & Industry & $\underline{\text { Firms }}$ & $\begin{array}{l}\text { Total } \\
\text { write-off }(\$ M)\end{array}$ & $\begin{array}{l}\text { Average } \\
\text { per firm }(\$ M)\end{array}$ \\
\hline 4800 & Communication & 9 & 2161.5 & 240.2 \\
\hline $2000-3000$ & Manufacturing & 72 & 1936.7 & 26.9 \\
\hline $46,47,4900$ & Utilities & 34 & 457.0 & 13.4 \\
\hline 6000 & Financial & 9 & 209.3 & 23.3 \\
\hline 1000 & $\begin{array}{l}\text { Mining and } \\
\text { Construction }\end{array}$ & 7 & 126.2 & 18.0 \\
\hline 5000 & Wholesale-Retail & 6 & 63.4 & 10.6 \\
\hline 4000 & Transportation & 4 & 37.8 & 9.5 \\
\hline 7000 & Services & 4 & 29.1 & 7.3 \\
\hline \multirow[t]{2}{*}{000,8000} & Other & 2 & 18.5 & 9.3 \\
\hline & & 147 & 5039.4 & \\
\hline
\end{tabular}

Closer examination of the dollars-by-industry breakdown provides additional insights. First, the nine communications firms wrote off the highest total amount, but the legislation affected far more manufacturing firms, 72 in total. The average amount written off by communications firms was $\$ 240.2$ million, compared to only $\$ 26.9$ million for manufacturing firms. The communications firms' average is skewed by the extraordinarily large write-offs by two companies, AT\&T (\$995 million) and Verizon (\$962 million)-two companies that were subjects of congressional investigation. The next highest communications company write-off was by Qwest, at only $\$ 113$ million. With AT\&T and Verizon removed from the sample, the average communications company write-off was $\$ 29.2$ million, much closer to the manufacturing companies' average.

Manufacturing is a broad industry encompassing many activities and products. Within manufacturing, capital goods producers accounted for most of the write-offs. This sub-industry includes Caterpillar and Deere \& Co., the two other companies the House Committee investigated. Combined, 20 capital goods manufacturers wrote off $\$ 725$ million total, more than one-third of the manufacturing total. The second highest total was accrued by pharmaceutical manufacturers, which includes six companies that wrote of a total of $\$ 584.5$ million. The third highest manufacturing sub-industry included 20 material manufacturers that wrote off a total of $\$ 299.9$ million. ${ }^{133}$

132. Standard Industrial Classification (SIC) codes, as utilized by the U.S. Department of Labor and U.S. Securities and Exchange Commission.

133. The two largest pharmaceutical write-offs were by Pfizer ( $\$ 270$ million) and Merck ( $\$ 147$ million). Material manufacturers include PPG Industries, ALCOA, International Paper, and U.S. Steel. The largest writeoff in this industry was $\$ 85$ million. Sub-industries are defined by Standard \& Poor's GICS classifications. GICS (Global Industry Classification Standard), S\&P DOW JONES INDICES, http://us.spindices.com (last visited Jan. 5, 2013). 
Another industry represented significantly in our sample was utilities. Our data include 34 utilities companies that wrote-off RDS tax assets totaling \$457 million, putting the utilities industry in third place behind telecommunications and manufacturing for total assets written off. The utilities totals are somewhat unique, however, because the additional costs are often passed directly onto utilities customers (rate-payers). Accordingly, the loss of the tax asset often resulted in a new regulatory asset (a receivable from future rate payers) rather than a reduction in earnings. It is possible that additional utilities companies, not included in our sample, did not report the write-offs because there was no effect on current earnings. Nevertheless, utilities companies were statistically overrepresented among write-off companies.

Finally, although we found that the finance industry accounted for only four percent of the write-offs and that the number of finance firms reporting write-offs was statistically underrepresented, the average write-off per financial company was quite high. Only nine finance companies reported RDS write-offs, meaning that the $\$ 209.3$ million total written off by these firms represents an industry average of $\$ 23.3$ million, quite a bit higher than the $\$ 13.4$ million utilities average. These data suggest that finance firms that do offer retiree benefits tend to offer relatively generous benefits.

In sum, the industry data do not suggest a particular political motivation among the more highly represented industries. Rather, these industries tend to provide retiree health benefits at higher rates and more generous packages than other industries. It is expected that those industries would experience greater (i.e., more material) financial impact due to the change in tax treatment for the RDS subsidy and would have greater political stakes in the new law. Those interests readily explain these firms' motivation for issuing SEC disclosure statements.

\section{Size}

To assess the association between company size and write-offs, we considered the number of people employed by the firms and two financial measures of company size: market capitalization and book value of assets. Both are consistent with larger firms reporting larger write-offs and do not suggest that larger firms are more likely to make politically motivated disclosures than smaller firms.

\section{a. Number of Employees}

On average, the write-off companies in our sample employed 31,000 workers as of 2009. This compares to an average of about 9000 employees for other Compustat companies. Not surprisingly, total write-offs are highly correlated with the number of employees (correlation is $.59, \mathrm{p}$-value $<.01$ ), and companies with more employees wrote off the largest amounts. 
Table 5: Write-offs by Number of Employees

\begin{tabular}{|c|c|c|c|c|c|}
\hline Industry & $\underline{\text { Firms }}$ & Average & $\underline{\text { Median }}$ & $\underline{\text { Min }}$ & $\underline{\text { Max }}$ \\
\hline Mining and Constr. & 7 & 3704 & 4000 & 175 & 9524 \\
\hline Utilities & 33 & 3017 & 2248 & 373 & 15,393 \\
\hline Communication & 9 & 1965 & 1672 & 198 & 4315 \\
\hline Financial & 8 & 1651 & 1705 & 317 & 4196 \\
\hline Mgmt. Consulting & 1 & 1364 & 1364 & 1364 & 1364 \\
\hline Manufacturing & 72 & 880 & 658 & 42 & 3892 \\
\hline Services & 4 & 832 & 320 & 86 & 2600 \\
\hline Transportation & 4 & 413 & 311 & 84 & 944 \\
\hline Ag., Forest., Fish. & 1 & 296 & 296 & 296 & 296 \\
\hline \multirow[t]{2}{*}{ Wholesale-Retail } & 6 & 264 & 204 & 5 & 622 \\
\hline & 145 & 1572 & 877 & 5 & 15,393 \\
\hline
\end{tabular}

Average write-offs for firms with 25,000 or more employees exceeded $\$ 100$ million. Firms with 10,000 to 25,000 employees wrote off about $\$ 20$ million. The average writeoff per employee was $\$ 1572$, and the range was from about $\$ 5$ to around $\$ 15,000 .{ }^{134}$ By way of comparison, in 2012, retiree-only health benefit plan (including comprehensive, not just prescription drug plans) annual premiums averaged $\$ 8419$ for retirees under age 65 , and $\$ 4511$ for Medicare-eligible retirees over age 65 . Employers typically cover $50 \%$ or less of those annual premium costs. ${ }^{135}$

There were significant differences in per-employee expenses across industries. On average, the seven mining and construction firms and the 33 utilities firms wrote off more than $\$ 3000$ per employee. Medians and maximums were also highest for these industries, indicative of generous plans for these highly unionized industries. The next highest amounts were in the communication and financial industries, which averaged nearly $\$ 2000$ per employee. In contrast, the wholesale and retail industries wrote off an average of just $\$ 264$ per employee. The industry differences are statistically significant (ANOVA p-value $<.01)$.

134. National Fuel Gas Company (NFG) had the highest per-employee write-off $(\$ 15,393$ per employee). NFG is a New York utility that reported 1949 full-time employees at the end of 2009, see National Fuel Gas Company, Annual Report (Form 10-K) (Nov. 25, 2009), available at http://sec.gov/Archives/edgar/data/ $70145 / 000095012309066226 / 137851$ e10vk.htm, and wrote off tax assets of either $\$ 27.5$ million or $\$ 30$ million, as reported in the company's 10-K and 10-Q, respectively. National Fuel Gas Company, Annual Report (Form 10-K) (Nov. 24, 2010), available at http://sec.gov/Archives/edgar/data/70145/000095012310108604/ 140830e10vk.htm; National Fuel Gas Company, Quarterly Report (Form 10-Q) (Aug. 6, 2010), available at http://sec.gov/Archives/edgar/data/70145/000095012310074068/0000950123-10-074068-index.htm. This write-off did not affect earnings because the amount was added to rate-payers' obligations. The second highest per-employee write-off was about $\$ 9500$. Employee data were unavailable for two sample companies.

135. See TOWERS WATSON, supra note 6 , at 8 (showing annual premiums in both categories and employer and employee shares of premiums). 
As expected, higher per-employee amounts were associated with more prominent SEC disclosures. Excluding the outlier discussed previously, ${ }^{136}$ the next table reveals that the average per-employee write-off is highest when companies issued Form 8-K solely to disclose the write-off or when the write-off is prominent in the earnings announcement. Median differences are significant $(p$-value $=0.01)$.

\section{Table 6: Per Employee Write-offs by Disclosure Venue}

\begin{tabular}{|c|c|c|}
\hline \multirow{2}{*}{\multicolumn{3}{|c|}{ ypes of Form 8-K disclosures: }} \\
\hline & & \\
\hline Write-off is purpose of $8-\mathrm{K}$ & 1767.6 & 1443.3 \\
\hline Earnings release-write-off prominent & 1660.3 & 1514.8 \\
\hline Earnings release-write-off not prominent & 1024.4 & 710.5 \\
\hline Scheduled periodic filings & 1557.9 & 782.8 \\
\hline Sample total & 1476.2 & 861.5 \\
\hline
\end{tabular}

This result is consistent with prior analyses indicating that companies used Form 8$\mathrm{K}$ to disclose relatively material write-offs.

\section{b. Assets and Market Capitalization}

On average, our sample consists of relatively large companies. For fiscal year 2009, the average assets for our sample were $\$ 26.5$ billion, revenues were $\$ 11.6$ billion, and market capitalization was $\$ 13.2$ billion. These data compare to average assets of $\$ 12.3$ billion, revenues of $\$ 3$ billion, and market capitalization of only $\$ 3.1$ billion for other Compustat companies during the relevant time period. ${ }^{137}$ Consistent with this analysis, $53 \%$ of our sample companies are in Standard \& Poor's S\&P 500 Index, representing $15 \%$ of all Index companies. ${ }^{138}$ That said, some of the companies we included in our sample are relatively small; the smallest company reported assets of $\$ 78$ million and revenues of $\$ 83$ million, and medians are much smaller than averages for all groups, suggesting that a few larger companies drove up the overall averages.

136. See AMH Holdings, LLC, supra note 123.

137. Compustat is a commercial database providing researchers and investors with financial information for the vast majority of publicly traded companies. For 2009 , it includes financial data for nearly 10,000 companies.

138. $S \& P$ 500, S\&P DOW JONES INDICES, http://www.standardandpoors.com/indices/sp-500/en/us/?index $\mathrm{Id}=$ spusa-500-usduf--p-us-1-- (last visited Jan. 5, 2013). 
Table 7: Relative Size and Profitability of Write-off Companies

$\begin{array}{llll} & & \begin{array}{l}\text { Write-off } \\ \text { Companies }\end{array} & \begin{array}{c}\text { Other Compustat } \\ \text { Companies }\end{array} \\ \text { Assets (\$M) } & \text { Average } & 26.5 & 12.3 \\ & \text { Median } & 8.1 & 0.4 \\ \text { Revenues (\$M) } & \text { Average } & 11.6 & 3.0 \\ \text { Market capitalization (\$M) } & \text { Median } & 4.1 & 0.2 \\ & \text { Average } & 13.2 & 3.1 \\ \text { Return on assets } & \text { Median } & 3.7 & 0.2 \\ & \text { Average } & 3.4 \% & -7.4 \% \\ \text { Percent profitable } & \text { Median } & 2.7 \% & 0.4 \% \\ & & 82 \% & 54 \%\end{array}$

The companies in our sample were also relatively profitable. Of those companies, $82 \%$ reported net income (as opposed to net losses), compared to $54 \%$ of other Compustat companies. The average return on assets (ROAs) for the write-off companies was about $3 \%$, after adjusting for outliers, while the similarly adjusted average for other Compustat companies was close to $-7 \% .{ }^{139}$

The write-offs declined predictably with firm size. Again, these results were unsurprising as larger firms are better able to bear the costs of both active employee and retiree health plans and therefore more likely to offer such benefits. Also, the tax impact of the RDS change would more likely be "material" on larger firms.

In sum, firm demographics suggest little about the political motivation behind firms' RDS-related SEC disclosures. Any trends in industry type or firm size are as readily explained by historical patterns of firms offering retiree benefits. Larger, longer established, and unionized companies are more likely to offer those benefits. Accordingly, those firms are more likely to report a material impact on expected earnings as a result of the change in tax treatment to the RDS following enactment of the ACA. At the same time, those firms are more likely to have a political interest in the federal health reforms Congress is enacting.

\section{Lobbying and Subsequent SEC Disclosure}

In another attempt to identify possible political motivation for the SEC disclosures, we looked at the lobbying history of the firms in our sample. We found that firms that lobbied on the ACA were almost twice as likely to issue 8-Ks related to the RDS issue and wrote off significantly higher amounts, on average, than non-lobbying firms.

139. This average is calculated after excluding companies with the highest and lowest five percent of ROAs from each group. These extreme ROAs are excluded because outliers can have a significant effect on the average. For example, companies with very few assets often have extremely high or low ROAs as the denominator approaches zero. 
Of the 147 write-off companies, 43 lobbied on the ACA. ${ }^{140}$ The average write-off for those 43 firms was $\$ 92.5$ million, compared to a much lower average of $\$ 10.2$ million for non-lobbying firms. As shown in Table 8, medians and totals were also significantly higher. In addition, among the 43 lobbyists, 27 (or 63\%) issued 8-Ks related to the RDS issue. By comparison, among the 103 non-lobbyists, only 38 (or $37 \%$ ) issued 8 -Ks. Finally, lobbying was much more prevalent among firms that issued a Form $8-\mathrm{K}$ solely for the purpose of disclosing the write-off.

Table 8: Write-offs and Lobbying

Issued

Amounts Written off by:

Average

Median

$\underline{\text { Total }} \quad \underline{8-\mathrm{K}}$

Firms that lobbied

28.0

3976.9

$63 \%$

Firms that did not lobby

10.2

4.5

1062.5

$37 \%$

Percent of Each Disclosure Group Lobbying:

Type of Form 8-K disclosures:

$\begin{array}{ll}\text { Write-off is purpose of } 8-\mathrm{K} & 73 \% \\ \text { Earnings release-prominent } & 39 \% \\ \text { Earnings release-not prominent } & 28 \% \\ \text { Scheduled periodic filings } & 20 \%\end{array}$

There is also considerable anecdotal evidence of lobbying around the proposed RDS tax change. ${ }^{141}$ As the Minority Committee memorandum details, several companies wrote to members of Congress during the health reform debate, explaining that the proposed provision would require them to take substantial write-offs if the nondeductibility provision passed. ${ }^{142}$ Also, industry representative organizations, including most notably the American Benefits Council, followed the RDS tax change issue closely, taking out full-page advertisements in Politico and Roll Call. ${ }^{143}$

140. Ctr. for Responsive Politics, Lobbying: Health Issues-Issue Profile, 2010, OPENSECRETS.ORG, http:/www.opensecrets.org/lobby/issuesum.php?id=HCR\&year=2010 (last visited Jan. 5, 2013). This source does not detail whether the firms lobbied for or against that ACA, or the provisions on which they focused their lobbying efforts.

141. See King, supra note 129 ("Some of the biggest employers in the U.S. are warning that a provision in the Senate's proposed health-care overhaul could lead to cuts in retiree benefits and a sharp reduction in reported earnings next year.").

142. See Minority Memo, supra note 81 , at 2-3 (noting that all four investigated companies signed letters to members of Congress warning of the impact of the change); see, e.g., Letter from James Bell et al. to Harry Reid, Senate Majority Leader, and Nancy Pelosi, Speaker of the House of Representatives (Dec. 11, 2009), available at http://www.americanbenefitscouncil.org/documents/hcr_drugsub_cfo-letter121109.pdf (citing concerns about the impact of the proposed Medicare Part D subsidy; seven of the ten signatories to the letter were firms in our dataset, including Boeing, Caterpillar, Con-way, Inc., Deere \& Co., Met Life, Verizon, and Xerox).

143. See Our Issues-Health: Retiree Healthy/ERRP, AM. BENEFITS COUNCIL, 
The apparent correlations between lobbying and both disclosure venue and disclosure amount could suggest that Form $8-\mathrm{K}$ filers were particularly politically motivated in issuing real-time disclosures in the wake of the ACA. But the preceding analysis offers alternative, equally plausible explanations. Firms experiencing greater financial impact due to the RDS tax change were more likely to identify that event as material, thus triggering the Form 8-K disclosure requirement. Moreover, firms that historically provided more generous retiree drug benefits through the RDS could readily have anticipated the financial impact of the non-deductibility proposal. The issue would have been on these firms' political radar screens during congressional debates, providing a rational basis for lobbying against the change in tax treatment. The fact that these firms were both politically opposed to the law and financially obligated to report the effect of the change in the law does not suggest improper political motive in filing the $8-\mathrm{K}$ disclosures.

\section{E. Market Nonresponse}

For reasons explained below, the 147 sample firms' SEC disclosure statements, writing off a total of $\$ 5$ billion against 2010 expected earnings, did not produce a statistically significant market response. Such startlingly large earnings write-offs from numerous S\&P 500 firms might be expected to cause a decrease in market values at the time of the disclosures. Alternatively, if the market viewed the firms' political statements expressing criticism of the ACA favorably, an increase in market values at the time of disclosure would be plausible. ${ }^{144} \mathrm{We}$ found neither of these effects.

\section{Prediction Market for ACA Enactment}

Market response to an event is based upon a number of factors, including the extent of an anticipated event. Using data from Intrade, an online prediction market, to evaluate the public's assessment of the likelihood that the ACA would pass, we found that it took until the final two weeks prior to enactment for the market to anticipate that passage was more likely than not (or greater than $50 \%$ ). ${ }^{145}$ Intrade allows traders to purchase ("go

$\mathrm{http}: /$ www.americanbenefitscouncil.org/issues/health/retiree.cfm (last visited Jan. 5, 2013); Bridge Years Health Coalition, Advertisement: Retiree Drug Coverage: Don't Fix What Ain't Broke, Politico, Dec. 10, 2009, at 37-38, available at http://www.americanbenefitscouncil.org/documents/hcr_drugsub_ads 121009.pdf (criticizing a proposed tax on benefits); see also Companies Begin to Report Healthcare Bill "Bill", PLANSPONSOR (Mar. 26, 2010), http://www.plansponsor.com/Companies_Begin_to_Report_Healthcare_Bill _Bill.aspx (quoting American Benefits Council President, noting that the organization, "along with several employers and labor unions, warned that the retiree drug subsidy tax in the health care legislation would impose an enormous hit on company financial statements as soon as the bill was signed into law").

144. See Coffin, supra note 8, at 134-50 (testing three hypotheses for market response to corporate political speech following the Citizens United decision, finding no significant response); Jeff Milyo, Stock Market Reactions to Political Events: What Can We Learn About the Efficacy of Political Connections? 6-12 (George Mason University Mercatus Ctr., Working Paper No. 12-15, May 2012), available at http://mercatus.org/sites/default/files/stock-market-reactions-political-events.pdf (citing studies which examine the stock market reaction to the Bush v. Gore decision, Senator Jeffords's party switch, death of U.S. Senators, impeachment of President Clinton, passage of Bipartisan Campaign Finance Reform Act of 2002 (McCainFeingold), and Citizens United).

145. Panos Ipeirotis, Associate Professor and George A. Kellner Faculty Fellow, Leonard N. Stern School of Business, New York University, Intrade Archive, http://intrade-archive.appspot.com/ (last visited Jan. 5, 
long") or sell ("go short") on contracts/trades on the outcome of specific future events. Intrade contracts payout $\$ 10$ if the event occurs; otherwise the payout is $\$ 0$. The trades are priced between $\$ 0$ and $\$ 100$, meaning that each point is equivalent to $\$ .10$ (100 points $/ \$ 10) .{ }^{146}$ The results of daily trades can be interpreted as the market's assessment of the likelihood of a given event occurring.

On January 19, 2010, Intrade opened a trading market for "OBAMACARE.PASS.JUN10,"147 described as "Obamacare' health reform to become law before midnight ET June 30, 2010."148 On March 4, 2010, the probability of ACA enactment exceeded $50 \%$ for the first time since congressional consideration of the legislation began, with trading prices ranging from $\$ 39$ to $\$ 89.9$ on that volatile day. In the subsequent ten days, closing prices hovered between $\$ 45$ and $\$ 65$. By March 19 , two days before passage, and four days before President Obama signed it into law, the probability of ACA enactment reached $80 \%$, suggesting that the market anticipated passage and had time to price in the likely effects of the new legislation. ${ }^{149}$ Accordingly, the market showed no statistically significant response to passage, or to firms' postpassage SEC disclosures. In effect, the market had already absorbed the information regarding the expected financial impact of the RDS tax change.

Figure 1: Intrade Contract Trading Prices for ACA Passage Before 6/30/10

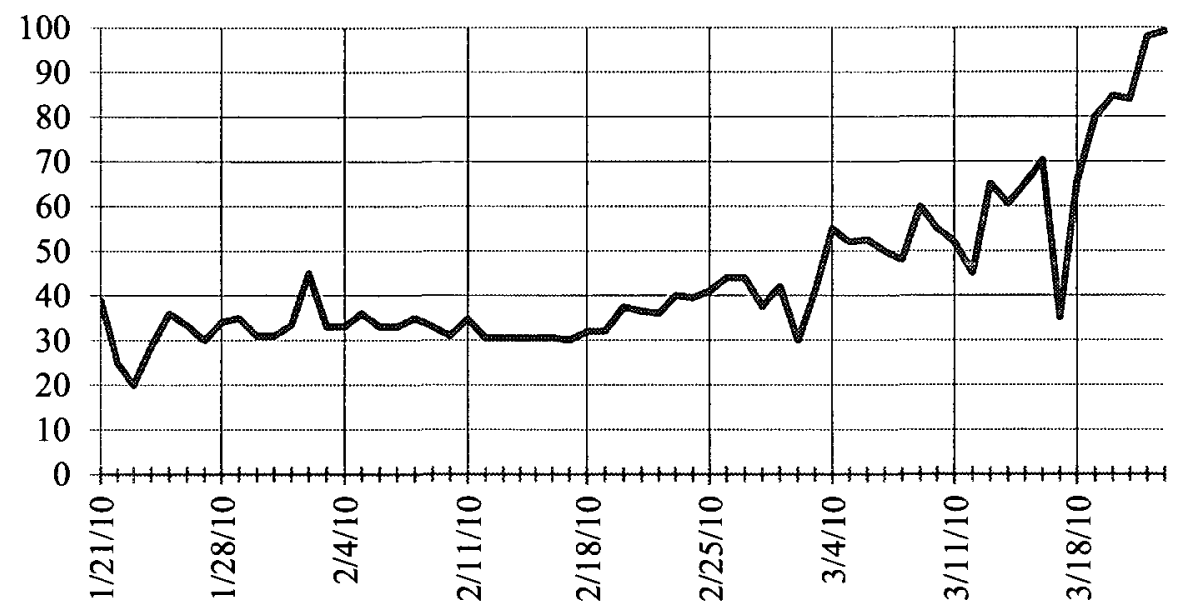

\section{Stock Market Response to ACA Enactment}

Because SEC disclosures are intended to provide relevant information about firms' financial performance, ${ }^{150}$ one might expect the public reports of alarmingly high writeoffs to cause the disclosing companies' share values to decline after the SEC filings are

2013) (data available upon request).

146. Id.

147. Id.

148. Id.

149. Interestingly, on March 17, 2010, the probability dropped to $35 \%$.

150. Securities Act of 1933,15 U.S.C. $\$ 77 \mathrm{a}(2012)$. 
issued. ${ }^{151}$ To test this hypothesis, we analyzed the market returns for the 15 firms issuing Form 8-Ks solely for the purpose of reporting the write-off. We focused on these disclosures for two reasons: first, as discussed above, ${ }^{152}$ these tend to be the largest write-offs and are most likely to trigger significant reactions. Second, because these Form 8-Ks provided information exclusively about the RDS-related write-offs, it is reasonable to attribute the market response to that news. By contrast, for the Form 8-Ks that also included other earnings news, it is difficult to disentangle the impetus for the response.

Our analysis employed cumulative abnormal returns (CARs). We used price data from the Center for Research on Securities Prices (CRSP) and the Eventus Event Study statistical program to calculate the returns for each of these 15 companies over a two-day event window, beginning on the date the company filed the Form 8-K and continuing through the next trading day. ${ }^{153}$ For each of the 15 companies, Eventus estimated the abnormal return on the date that the $8-\mathrm{K}$ was filed (day zero) and the trading date immediately after (day one). We estimated the abnormal return by subtracting the average overall market return for the day from the daily return for the disclosing company. This procedure removed the portion of the company's return due to general market activity, leaving the idiosyncratic return for the particular firm. Conceptually, one could consider any abnormal return a function of new information specific to the disclosing company. We cumulated the abnormal returns for the two-day event window by summing. Next, we used a t-test to assess whether the abnormal returns for the 15 firms, either individually or in aggregate, were significantly different from zero. If not, then the disclosures did not have significant effects on the stock prices of the disclosing firms. This analysis revealed that the market response with respect to the studied firms was not statistically significant. As the Intrade analysis suggested, information about the effect of the RDS tax change and the potential write-offs was already impounded in the market price.

It is not surprising that this information was already publicly available. As noted above, ${ }^{154}$ several of the firms in our sample lobbied against the change and advised elected officials and government officials that they would be required to take the writeoffs if Congress enacted the new RDS non-deductibility rule.

\section{Prediction Market for Supreme Court ACA Decision}

By way of comparison, consider the prediction market results for judicial resolution of the constitutionality of the ACA. Intrade opened three prediction markets, varying by the expected date of the U.S. Supreme Court ruling on the individual mandate in National Federation of Independent Business $v$. Sebelius. ${ }^{155}$ HEALTHCARE.UNCONST.OCT 11 , HEALTHCARE.UNCONST.DEC12, and HEALTHCARE.UNCONST.DEC13, described as " $t]$ he US Supreme Court to rule individual mandate unconstitutional before

151. John A. Elliot \& Wayne H. Shaw, Write-offs as Accounting Procedures to Manage Perceptions, $26 \mathrm{~J}$. ACCT. RES. SUPPLEMENT 91, 93 (1988) (providing a detailed analysis of share declines after write-downs).

152. See supra Part IV.B (describing disclosure venue and amounts written off).

153. The two-day window allows for either a disclosure filed after market close or an otherwise incomplete reaction to the Form $8-\mathrm{K}$ news on the date of filing. We also consider a three-day window (days -1 to 1 ) to allow for news leakage prior to the filing date. Results are unchanged.

154. See supra note 140 and accompanying text (noting corporate opposition to health care reform).

155. Nat'l Fed'n of Indep. Bus. v. Sebelius, 132 S. Ct. 2566 (2012). 
midnight ET 31 Oct 2011" (with identical markets available for the dates 31 December 2012 or 31 December 2013). ${ }^{156}$ All three markets opened on April 12, 2011, and closed after the court ruled on June $28,2012 .{ }^{157}$ The figure below presents the trading prices for the latter two markets from December 28, 2011, through June 28, 2012. ${ }^{158}$

\section{Figure 2: Intrade Contracts' Trading Prices for Supreme Court Ruling on ACA}

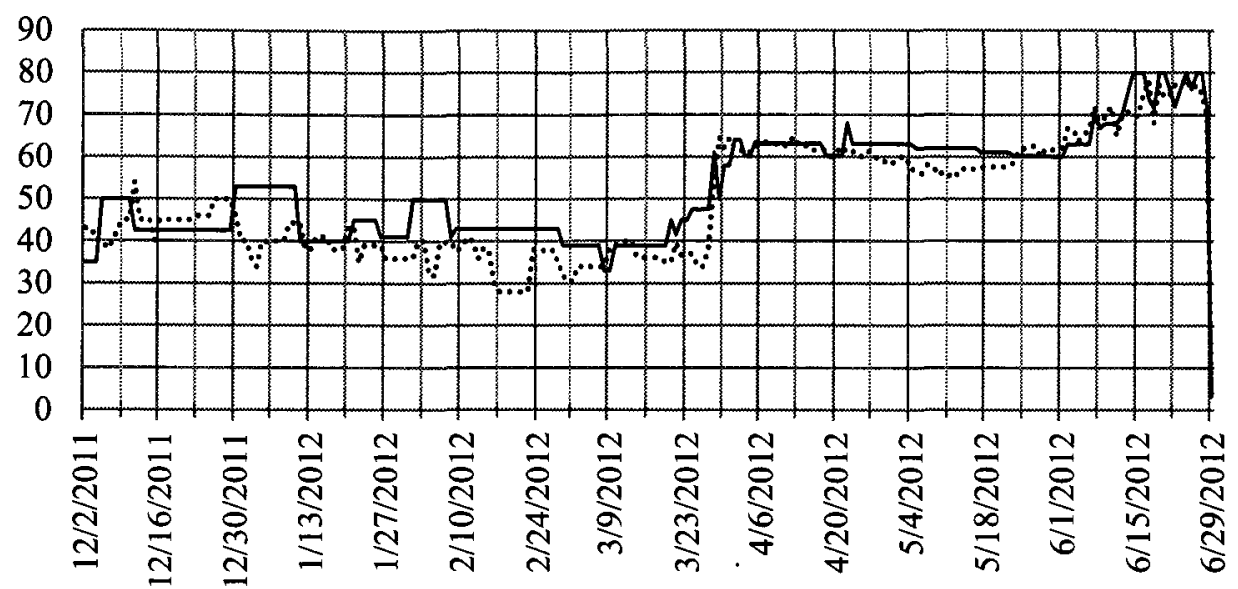

\section{HEALTHCARE.UNCONST.DEC12}

\section{HEALTHCARE.UNCONST.DEC13}

As demonstrated, the trading prices are related with an increased correlation as time passed. By early March 2012, the two markets were trading at nearly identical prices, but still below 40.159 After three days of oral arguments on the case in late March, however, Intrade's betting shifted dramatically, climbing to over $60 .{ }^{160}$ Traders perceived the tone and extent of the Justices' questioning and the attorneys' responses to favor the side challenging the mandate's constitutionality. ${ }^{161}$ On June 27,2012 , the day before the Supreme Court's decision, the December 2012 market traded at $\$ 69.5$, and the December 2013 market traded at $\$ 71.7 .162$ Because the trading volume was high (over 11,000 trades in the three-day window around the Court's announcement), these results cannot be attributed to a few outliers moving the market. ${ }^{163}$ To the surprise of many, including the

156. The U.S. Supreme Court to Rule Individual Mandate Unconstitutional Before Midnight ET 31 OCT 2011, INTRADE, http://www.intrade.com/v4/markets/contract/?contractId=719011 (last visited Jan. 5, 2013).

157. Ipeirotis, supra note 145 .

158. Id.

159. $I d$.

160. Id.

161. See Nate Silver, Overconfidence Suggested in Supreme Court Predictions, N.Y. TMES, June 27, 2012, http://fivethirtyeight.blogs.nytimes.com/2012/06/27/overconfidence-suggested-in-supreme-courtpredictions/ (describing Intrade shifts).

162. Ipeirotis, supra note 145 .

163. Id. 
Intrade prediction market, the Supreme Court, on July 28, 2012, upheld the mandate under the federal taxing power. ${ }^{164}$

Thus, it appears that the market assessed, with moderate success, the likelihood of ACA passage, but failed to predict the Supreme Court's individual mandate decision. The Court's firm nondisclosure policy regarding cases pending before it may have caused this error. ${ }^{165}$ By contrast, the public legislative process surrounding the ACA's enactment allowed for much greater information sharing. While the Justices signaled the date of the ruling, ${ }^{166}$ reliable information, analogous to the legislative votes and lobbying activity surrounding the ACA enactment that would clearly signal the Court's expected outcome remained significantly less transparent. It is likely that media and popular sentiment over the anticipated outcome likely swayed the prediction market for the Supreme Court's decision, especially given the scarcity of other authoritative sources. ${ }^{167}$

\section{FINDINGS AND IMPLICATIONS}

Our findings, based on a comprehensive study of 147 firms' post-ACA SEC disclosures reporting adverse financial impact as a result of the RDS tax change, are consistent with the congressional committee's conclusions regarding four companies' dramatic Form 8-K disclosures. ${ }^{168}$ At first blush, a prominent company's publicly filed statement, issued immediately upon the ACA's enactment, reporting a jaw-dropping $\$ 1$ billion write-off, might appear to be nothing more than a political statement against "Obamacare." But, if not strictly required by law, AT\&T's and other companies' disclosures were certainly permitted under the SEC's flexible standards for reporting "material" changes. In addition, the calculations of 2010 current-year write-offs, representing already-deferred tax benefits, were consistent with FAS rules.

Our study took a deeper, more comprehensive look at the SEC disclosures that triggered the aborted congressional inquiry. We included not just real-time Form 8-K disclosures filed immediately after the ACA was enacted, but also scheduled periodic filings (Forms $10-\mathrm{Q}$ and $10-\mathrm{K}$ ) filed in the relevant quarter following enactment. ${ }^{169}$

164. Charles Fried, The June Surprises: Balls, Strikes, and the Fog of War, SCOTUSBLOG (Aug. 2, 2012, 12:19 PM), http://www.scotusblog.com/2012/08/the-june-surprises-balls-strikes-and-the-fog-of-war/; see, e.g., Liz Halloran, Legal Scholars React: "Many People Were Stunned", IT's ALl POLITICS Blog (June 28, 2012, 1:15 PM), http://www.npr.org/blogs/itsallpolitics/2012/06/28/155919089/legal-scholars-react-many-peoplewere-stunned (compiling reactions from scholars and lawyers).

165. See Kyle Cheney, On Eve of Health Ruling, Ruth Bader Ginsburg Predicts "Sharp Disagreement", POLITICo (June 15, 2012), http:/www.politico.com/news/stories/0612/77479.html (quoting Justice Ruth Bader Ginsburg regarding the Court's pending decision: "Those who know don't talk. And those who talk don't know.").

166. See U.S. Supreme Court Procedures: Opinions, ADMIN. OFF. OF THE U.S. CouRTS, http:/www.uscourts.gov/EducationalResources/ConstitutionResources/SeparationOfPowers/USSupremeCourtP rocedures.aspx (last visited Jan. 5, 2013) (stating that all opinions of the Court are typically handed down by the last day of the term).

167. See Rob Savillo, Media Overwhelmingly Focus on Rulings Against Health Care Reform Constitutionality, MEDIA MATTERS (June 22, 2012, 11:46 AM), http://mediamatters.org/research/2012/06/22/ report-media-overwhelmingly-focus-on-rulings-ag/185745 (explaining that news reports indicated that Americans believed the individual mandate was unconstitutional).

168. See supra Table 1.

169. The U.S. Chamber of Commerce initially tabulated "at least 40 companies" that took charges against 
Attempting to reveal political motivation for the RDS-related disclosures, we sorted the data through various filters, including disclosure venue (by both amount disclosed per venue and primary purpose of the disclosure), industry type, firm size (by both number of employees and assets/market capitalization), and lobbying history of the sample firms. We also considered market response to the disclosures to see whether the disclosing firms experienced a loss (due to the adverse financial reports) or gain (indicating support for their political statements) in share value upon release of their SEC filings.

In each analysis, our findings did not suggest primary political motivation. The results were readily explained by SEC disclosure standards (e.g., firms experiencing larger financial impacts tended to deem the RDS change "material," thereby triggering the 8-K filing), industry trends (e.g., larger, more established, and unionized industries tend to provide retiree benefits at higher rates than other industries, thereby experiencing greater financial impact from the RDS change), or rational self-interest in the new law (e.g., firms that lobbied on the ACA, generally, and RDS, specifically, had larger financial stakes in the legislation than firms that did not). Those conclusions aside, we recognize that the RDS-related SEC disclosures may serve dual purposes as compelled, regulated speech and a form of corporate political speech.

\section{A. Uniquely Reportable Event}

The RDS tax change offered a uniquely reportable event that companies opposing federal health care reform could use to signal objection to the ACA in the days immediately following the law's enactment. ${ }^{170}$ A perfect storm of factors created this opportunity. No other provision of the ACA required firms to take an immediate charge against 2010 expected earnings. The combined operation of accounting standards and SEC disclosure requirements rendered the RDS tax change a uniquely reportable event. Unlike any other ACA provision applicable to employers, the elimination of deductibility for the RDS subsidy required firms to recognize an immediate financial impact in the form of a non-cash charge against expected earnings in the same quarter as the ACA's

earnings totaling $\$ 3.4$ billion, compared to our comprehensive total of 147 companies, totaling $\$ 5$ billion in write-offs. See Pear, supra note 65 (noting that companies cannot quantify benefits until the law is enacted).

170. In game theory, signaling is a strategy used by repeat players to communicate willingness to cooperate. See generally ERIC A. POSNER, LAW AND SOCIAL NORMS 18-20 (2000) (using game theory to describe how "good" and "bad" types interact in a prisoner's dilemma scenario); Eric A. Posner, Symbols, Signals, and Social Norms in Politics and the Law, 27 J. LEGAL STUD. 765, 768 (1998) (describing the signaling model, labeling game citizens of the high type as "cooperators" and the low type as "cheaters"). Players can be grouped into two types: "good," or cooperative, types who value the future highly relative to the present and are willing to wait for future payoffs, and "bad," or opportunistic, types who seek payoffs in the present, even if it means sacrificing future payoffs. The more one discounts the future, the less likely one is to forego the immediate benefit gained from defection ("good" types). Accordingly, players attempt to identify other "good" types with low discount rates. The model assumes that a person knows his type but does not know the types of others. To distinguish themselves from "bad" types and identify cooperative partners, "good" types engage in actions called signals, which refer to any behavior that is observable and has an associated cost. Id. The 147 firms identified in our study could be seen as taking the opportunity of SEC disclosures to signal to other "good" types their willingness to forego the immediate benefits of stable earnings expectations in order to derive the future benefits of a sustained cooperative relationship toward repeal or revision of the ACA's new burdens on employers. 
enactment. ${ }^{171}$ Moreover, accounting standards allowed firms to calculate extraordinarily high estimated write-offs, which made the impact of their disclosures especially salient as political statements against the ACA.

First, FAS 106 (now codified as ASC 715-60) affected a significant change in employers' accounting for post-retirement benefits other than pensions. ${ }^{172}$ The new standard requires accrual-basis, rather than pay-as-you-go, accounting. Accordingly, employers must report the expected cost of future benefits for employees and their beneficiaries and dependents during the years the employee renders the services necessary to earn the benefits. ${ }^{173}$ FAS 106 means that firms must include the cost of prescription drug benefits payable to current retirees, as well as expected costs of benefits to be paid to future retirees, in their current earnings statements. ${ }^{174}$

Second, FAS 109 (now codified as ACS 740) requires firms to recognize deferred tax assets and liabilities resulting from a change in tax laws or rates in the year of enactment. ${ }^{175}$ Accordingly, firms are required to take a noncash charge against current earnings, reflecting the entire present value of the deferred tax benefits. ${ }^{176}$

By contrast, other ACA provisions affecting employers, including the increased costs of covering more employees and dependents due to pay-or-play penalties, default enrollment for employers with 200 or more employees, and extension of dependent child coverage to age 26; increased costs for additional benefits due to ACA's coverage mandates; and costs associated with new reporting, disclosure, and accounting requirements surely will impact companies' future earnings statements. ${ }^{177}$ But those financial impacts can be incorporated into earnings forecasts or otherwise reported when the provisions take effect. None of those provisions required adjustments to firms' 2010 , current-year expected earnings. Even the "Cadillac Tax," a $40 \%$ excise tax on high-cost health that will take effect in $2018,{ }^{178}$ would not trigger current adjustments to expected earnings unless firms begin modifying their current plans to avoid the future tax. ${ }^{179} \mathrm{By}$ contrast, firms had already included the tax benefit expected from the RDS subsidy in their 2010 first-quarter earnings statements.

Third, SEC Form 8-K requires "rapid and current" 180 disclosure of material changes in a company's financial condition or operations, as quickly as four days after specific extraordinary events occur. ${ }^{181}$ Accordingly, firms deeming the financial impact of the

171. Committee Memo, supra note 49, at 3.

172. See supra Part III.B (explaining accounting standards).

173. FASB STATEMENT No. 106, supra note 75.

174. Id.

175. FASB STATEMENT No. 109, supra note 76.

176. Id.

177. See supra notes 6, 10-17 (citing ACA provisions applicable to employers and expected future impact on employee benefit plans).

178. See 26 U.S.C. $\S 4980$ I (2012) (detailing the coverage and requirements of the excise tax on high cost employer-sponsored health coverage).

179. See Brian Lane et al., A Summary of the Financial Reporting and Disclosure Implications of the Health Reform Legislation, DELOITTE \& GIBSON DUNN 4 (Apr. 2010), http://gibsondunn.com/publications /Documents/DeloitteGibsonDunn-SummaryFinancialReportingImplicationsOfHealthCareReform.pdf

(exhibiting a table demonstrating the business and financial impact of the excise tax).

180. Sarbanes-Oxley Act $\S 409,15$ U.S.C. $\S 78 \mathrm{~m}$ (2006).

181. Additional Form 8-K Disclosure Requirements and Acceleration of Filing Date, 67 Fed. Reg. 42,914, 42,914 (June 25,2002 ) (to be codified at 17 C.F.R. pts. 228, 229, 240, 249). 
change in tax treatment for the RDS subsidy material to their finances were required to report the impact very soon after either the final enactment of the ACA or the Reconciliation Act. ${ }^{182}$

Fourth, the materiality standard allows business judgment in determining which events are material and, therefore, reportable. Materiality judgments are particularly nuanced when involving estimates or other items incapable of precise measurement, items for which there is lack of clear authority on appropriate accounting methodologies, and forward-looking statements. ${ }^{183}$ All of those considerations were applicable to firms' estimated future costs and tax liabilities for retiree benefit plans. Most firms included in our study experienced a quantitatively material impact as a result of the RDS tax change. However, even firms that reported minimal financial impact might still deem the change qualitatively material and therefore reportable. Analysts are not capable of precisely estimating future retiree drug benefit costs given: 1) fluctuations in prescription drug costs over time; 2) potential changes in enrollment levels, should retirees opt for coverage on the exchanges or in Medicare Part D; and 3) life expectancy of retirees and other beneficiaries and dependents.

Moreover, the SEC recognizes that, in some cases, "reasonable minds may differ about the appropriate accounting treatment of a financial statement item," 184 which could lead to reasonably different interpretations of materiality. ${ }^{185}$ The House Committee highlighted the lack of consensus on the appropriate accounting methodology for future RDS tax liabilities, in relation to the expected duration of the benefits. ${ }^{186}$ Standard accounting practices suggest that firms calculate the present value of taxes they will pay over the estimated lifetimes of current and future retirees who are expected to receive the benefits. Accordingly, some companies calculated future losses out over a very long period of time (in one case to "infinity"), suggesting that they expected to continue offering prescription benefits without any abatement. 187 Other firms applied more conservative estimates of 30 years, perhaps reflecting the current reality that many employers are reducing or eliminating retiree benefits. Either approach, however, seems acceptable under accounting standards.

\section{B. Government Regulation of Corporate Political Speech}

This study develops an important subplot in the saga that has been the passage of, and challenges to, the ACA-the Obama Administration's attempts (and failures) to

182. See Deloitte Part D Subsidy Alert, supra note 118 (regarding discretion in determining March 23 or March 30 trigger date).

183. See supra Part III.A.2 (describing SEC materiality standard).

184. Bulletin No. 99, supra note 107, at 4 .

185. Id. at 7. "[L]ike materiality, 'reasonableness' is not an 'absolute standard of exactitude for corporate records." Id. (quoting Harold M. Williams, Chairman, SEC, Address at the SEC Developments Conference on the Accounting Provisions of the Foreign Corrupt Practices Act: An Analysis (Jan. 13, 1981), available at www.sec.gov/news/speech/1981/011381williams.pdf).

186. See Committee Memo, supra note 49, at 3 (stating that several different accounting methodologies are compliant with SEC standards).

187. Id.; see Maher et al., supra note 51 (noting that "[i]n 2004, companies booked billions of dollars in gains for the anticipated subsidies, but many later reduced benefits anyway"). 
manage the public message around the new law. ${ }^{188}$ The most recent, salient example of this miscalculation was the Supreme Court's holding in National Federation of Independent Business $v$. Sebelius, on June 28, 2012, that the ACA's minimum essential coverage requirement is unconstitutional under the Commerce Clause (although valid under the taxing power). ${ }^{189}$ Scholars, commentators, administration officials, pundits, reporters, and ACA supporters roundly dismissed states' challenges to the individual mandate as frivolous political stunts that lacked any legal merit. ${ }^{190}$

The Obama Administration remained mostly silent on the question of the mandate's constitutionality, while ACA opponents, including prominent pro-business organizations, hit the issue hard by developing novel legal theories to strike it down. ${ }^{191}$ Not surprisingly, public opinion about the ACA continued to decline. ${ }^{192}$ At the end of the

188. See Peter Baker, For Obama, a Signature Issue That the Public Never Embraced Looms Large, N.Y. TIMES, June 29, 2012, http://www.nytimes.com/2012/06/30/us/politics/health-care-overhaul-is-still-no-hit-withpublic.html?pagewanted=all (describing the Obama Administration's failure to develop and implement an effective strategy for communicating the benefits and rationale for health reform); Michael W. McConnell, The Liberal Legal Meltdown over ObamaCare, WaLL ST. J., May 24, 2012, http:/online.wsj.com/article/ SB10001424052702304707604577422923531419782.html (suggesting that supporters of mandatory insurance would offer legal arguments rather than moral accusations if they "were as confident of [the ACA's] merits as they claim to be").

189. Nat'l Fed'n of Indep. Bus. v. Sebelius, 132 S. Ct. 2566, 2601 (2012).

190. See, e.g., Sara Rosenbaum, A “Customary and Necessary" Program-Medicaid and Health Reform, 362 NEW ENG. J. MED. 1952, 1954 (2010) (stating that "the states' legal claims border on the frivolous"); Aziz Huq, Bad Law, Smart Politics in Constitutional Challenges to Healthcare Reform, THE NATION (Apr. 15, 2010), http://www.thenation.com/article/bad-law-smart-politics-constitutional-challenges-healthcare-reform ("Even a cursory glance at the Florida and Virginia complaints reveals that neither lawsuit really turns on a plausible reading of the law today."); Keith L. Martin, Law Professor: Health Reform Lawsuits in Va. Other States 'a Loser', INS. \& FIN. ADVISOR (May 18, 2010), http://ifawebnews.com/2010/05/18/law-professorhealth-reform-lawsuits-in-va-other-states-a-loser/ (calling Virginia attorney general's lawsuit challenging health reform mandates "a loser"); Elizabeth Weeks Leonard, Rhetorical Federalism: The Value of State-Based Dissent to Federal Health Reform, 39 HoFSTRA L. REV. 111, 116 (2011) (describing scholars' and courts' reactions to the lawsuits).

191. See, e.g., Brief for Cato Inst. et al. as Amici Curiae Supporting Respondents, Dep't of Health \& Human Servs. v. Florida, 132 S. Ct. 1133 (2012) (No. 11-398), available at http:/www.cato.org/pubs/ legalbriefs/HHSvF-Brief.pdf (arguing that "[t]he individual mandate exceeds Congress's power to regulate interstate commerce under existing doctrine"); Randy E. Barnett, Commandeering the People: Why the Individual Health Insurance Mandate Is Unconstitutional, 5 N.Y.U. J.L. \& LIBERTY 581, 604-14 (2010) (discussing legal theories regarding the unconstitutionality of the individual mandate); Ilya Somin, $A$ Mandate for Mandates: Is the Individual Health Insurance Case a Slippery Slope?, 75 LAW \& CONTEMP. PROBS. 75, 7580 (2012) (discussing a legal slippery slope argument regarding the individual mandate); David B. Rivkin \& Lee A. Casey, Illegal Health Reform, WASH. Post, Aug. 22, 2009, at A15 (arguing that Congress cannot impose a federal mandate that requires Americans to purchase health insurance); Ed Feulner, Morning Bell: Obamacare Is a Cancer That Must Go, FoundRY, Mar. 19, 2012 (advocating against the ACA); Thomas P. Miller, The Individual Mandate: Ineffective, Overreaching, Unsustainable, Unconstitutional and Unnecessary, AM. ENTERPRISE INST. (Mar. 23, 2012), http://www.aei.org/paper/health/healthcare-reform/ppaca/theindividual-mandate-ineffective-overreaching-unsustainable-unconstitutional-and-unnecessary/ (discussing the idea that the individual mandate is "unprecedented and not bound by any limiting principal"); see also Savillo, supra note 167 (noting media's disproportionate focus on lower court decisions striking down the ACA).

192. See, e.g., Kaiser Health Tracking Poll-May 20l2, KAISER FAM. FOUND., www.kff.org/kaiserpolls 18315.cfm (last visited Jan. 5, 2013) (finding that favorable public opinion of the ACA dropped five percent since April 2012, with unfavorable views now outnumbering favorable ones, $44 \%$ to $37 \%$ ); Adam Liptak \& Allison Kopicki, New Poll: The Supreme Court and the Health Care Law, N.Y TIMES, June 7, 2012, $\mathrm{http}: / /$ thecaucus.blogs.nytimes.com/2012/06/07/new-poll-the-supreme-court-and-the-health-care-law/ (noting 
day, the Supreme Court accepted the challengers' arguments, articulating a novel limit on the federal power to regulate existing activity, but not to compel new activity, as a means of regulating interstate commerce. ${ }^{193}$ The Administration, in the end, prevailed on the individual mandate challenge, albeit on a different legal theory, ${ }^{194}$ and also succeeded in salvaging much of the Medicaid program. ${ }^{195}$ Yet Administration spokespersons were notably circumscribed in their response; they did not trumpet the Court's decision or seize the opportunity to turn the tide of negative public opinion.

The SEC disclosure controversy regarding RDS-related write-offs, which this study examined closely, was among the Administration's first fumbled attempts to control the political message around the ACA. Congressional and Administration officials pounced on the high-dollar public filings as political statements asserting that the ACA would be bad for businesses and bad for employer-based health insurance, contrary to the Administration's own predictions that the ACA would actually lower health care costs in the long run. ${ }^{196}$ After a relatively brief investigation, the congressional committee called off the hearing, concluding that the firms' disclosures were proper, if misleading. ${ }^{197}$

Other Administration attempts to manage the message around the ACA are still playing out. Two regulations issued by the U.S. Department of Health and Human Services (HHS) will compel, rather than attempt to suppress, corporate speech. The compelled speech regulations aim, at least in part, to raise public opinion of the ACA. Specifically, the ACA requires health insurance companies to disclose certain pricing and profit information to health insurance customers. HHS contends that these disclosure requirements will increase transparency and accountability. ${ }^{198}$ However, regulators also

that only $24 \%$ of Americans hope that Supreme Court keeps the law as is); Dana Blanton, Fox News Poll: Majorities Say White House Failed on Economy, Health Care, Fox NEws (June 7, 2012), http:/www.foxnews.com/politics/2012/06/07/fox-news-poll-majorities-say-white-house-failed-on-economyhealth-care/ (finding that $52 \%$ of respondents think the Administration has mostly failed at improving health care).

193. Nat'l Fed'n of Indep. Bus., 132 S. Ct. at 2591 ("The individual mandate forces individuals into commerce precisely because they elected to refrain from commercial activity. Such a law cannot be sustained under a clause authorizing Congress to 'regulate Commerce."').

194. Id. at 2600 (concluding that the individual mandate "may reasonably be characterized as a tax" and that "the Constitution permits such a tax").

195. Id. at 2608 (limiting federal government's authority to condition states' existing Medicaid funds on Medicaid expansion and, instead, giving states the option to accept or reject the expansion and disagreeing with the joint-dissent that the entire ACA must fall).

196. See Committee Memo, supra note 49, at 4-5 (discussing expected cost reductions for employers); Gienger, supra note 69 (quoting letters from Waxman and Stupak to targeted companies, noting the ACA "is designed to expand coverage and bring down costs" and suggesting that the companies' statements "appear to conflict with independent analyses"); Susan Kelly, Hearing Set on Healthcare Charges to Earnings, TREASURY \& RISK (Apr. 1, 2010), http://www.treasuryandrisk.com/2010/04/01/hearing-on-healthcare-charges (quoting letters from Waxman and Stupak to targeted companies and citing Congressional Budget Office report estimating that large employers would experience a three percent decrease in average premiums by 2016).

197. See supra Part II.C (describing congressional investigation).

198. Your Insurance Company \& Costs of Coverage, U.S. DEP'T OF HEALTH \& HUM. SERVicES, http://companyprofiles.healthcare.gov/ (last visited Jan. 5, 2013) (describing two ACA provisions "that promote transparency and hold insurers accountable for how they spend your premium dollars and rate increases"); News Release, U.S. Dep't of Health and Human Servs., Affordable Care Act Holding Insurers Accountable for Premium Hikes (Jan. 12, 2012) [hereinafter News Release, Jan. 2012], available at http:/www.hhs.gov/ news/press/2012pres/01/20120112a.html ("Before the Affordable Care Act, consumers were in the dark about 
seem to hope that the statements will shift public opinion in favor of the ACA by focusing blame on insurers for escalating health-care costs while portraying HHS as a welcome regulator of a market run amok.

First, insurers in the individual and small-group market are subject to review and publication of "excessive" premium rate hikes, ${ }^{199}$ defined as any increase greater than $10 \%{ }^{200}$ HHS Secretary Kathleen Sebelius applauded the new rule, announcing the first such rate review of Everence Insurance: "We hope that by publicizing the excessive premium hikes, we will empower consumers." "By shining a light on unjustified premium increases, we will hold health insurers accountable like never before, [sic] and help keep money in the pockets of Americans." 201 HHS cited Everence for increasing its small business rates in Pennsylvania by $12 \% .{ }^{202}$ In January 2012, HHS determined that Trustmark Life Insurance Company had increased its rates by at least $13 \%$ in five states. ${ }^{203}$ Trustmark's premium increases for small businesses in Alabama and Arizona were $27.2 \%$ and $18.1 \%$, respectively. ${ }^{204}$ Further investigations followed, with HHS touting the reviews as bringing about fewer double-digit premium increases and eliciting "straight answers" from insurance companies. ${ }^{205}$ Companies identified for excessive premium hikes may either reduce their rates or submit a justification to the HHS Secretary and the relevant state. The companies are also required to "prominently post such information on their websites" within ten days of HHS' determination. 206

A second ACA provision compelling speech by insurers involves the medical-loss ratio (MLR). Health insurers in the individual and small group market are required to spend at least $80 \%$ of their premium revenues on medical care and quality improvement, and only $20 \%$ on overhead, profits, commissions, and other non-claim expenses. ${ }^{207}$ In the

their health insurance premiums because there was no nationwide transparency or accountability."); The 80/20 Rule: Providing Value and Rebates to Millions of Consumers, HEALTHCARE.GOV, http://www.healthcare.gov/ law/resources/reports/mlr-rebates06212012a.html (last visited Jan. 5, 2013) ("Because of the Affordable Care Act, insurance companies now must reveal how much of premium dollars they actually spend on health care and how much they spend on administration.").

199. Patient Protection and Affordable Care Act, Pub. L. No. 111-148, § 1003, 124 Stat. 119 (2010), amended by Health Care and Reconciliation Act of 2010, Pub. L. No. 111-152, 124 Stat. 1029 (2010) (to be codified at 42 U.S.C. $\S 18002)$; 45 C.F.R. $\$ 154$ (2011).

200. See Rate Review, HealthCARE.gov (Sept. 1, 2011), http://www.healthcare.gov/law/features/costs/ rate-review/ (explaining insurers' need to justify an increase of ten percent or more).

201. News Release, U.S. Dep't of Health \& Human Servs., Health Insurer Charging Unreasonable Rate Increases (Nov. 21, 2011) [hereinafter News Release, Nov. 2011], available at http:/www.hhs.gov/news/press/ 201 lpres/11/20111121a.html.

202. Id.

203. News Release, Jan. 2012, supra note 198; see also Robert Pear, U.S. Seeks Rollback of a Health Insurer's "Excessive" Rate Increase, N.Y TIMES, Jan. 12, 2012, http://www.nytimes.com/2012/01/13/health/ policy/white-house-calls-increases-in-health-insurance-rates-too-high.html (regarding Trademark rate increases).

204. News Release, Jan. 2012, supra note 198.

205. News Release, U.S. Dept. of Health \& Human Servs., Health Insurance Rate Hikes in Nine States Deemed Excessive by HHS (Mar. 22, 2012), available at http:/www.hhs.gov/news/press/2012pres/ $03 / 20120322 \mathrm{a} . \mathrm{html}$ (stating that insurers in the nine states requested rate hikes as high as $24 \%$ ).

206. Public Health Service Act $\S 2794(\mathrm{a})(2), 42$ U.S.C. $\S 300 \mathrm{gg}-94$ (2006), amended by Patient Protection and Affordable Care Act $\S 1003$ (codified as amended at 42 U.S.C. $\S 1800$ (2012)) (regarding ten-day timeframe).

207. Public Health Service Act $\S 2718(\mathrm{~b})(1)(9)(\mathrm{ii})$ (codified as amended at 42 U.S.C. $\S 300 \mathrm{gg}-18$ ) 
large group market, the ratio is $85 \%$ to $15 \%{ }^{208}$ The MLR also triggers rebate and disclosure obligations on insurers. Insurers that fail to abide by the applicable MLR must return rebates to subscribers and enrollees, based on the amount by which their actual MLRs exceeded the statutory limits. ${ }^{209}$ Companies had to begin assuming MLR rebates by August 1, 2012.210 An estimated 16 million Americans or their employers were expected to receive rebates totaling $\$ 1.3$ billion, based on insurers' 2011 MLRs. ${ }^{211}$ One commentator, noting that the Obama Administration has been "playing defensive" and "trying to convince a skeptical public" about the merits of the ACA, suggested that the MLR rebates will be "a true game changer in public attitudes about whether [the ACA] actually is beneficial and good public policy." 212

Although not required by the ACA, the Secretary of HHS also added a broad disclosure requirement to the MLR. As originally proposed, the HHS rule requires all insurers, including those that meet or exceed the statutory thresholds, to inform plan enrollees of their actual MLR performance for the current year as well as prior years, thereby allowing enrollees to evaluate the companies' performance over time. ${ }^{213} \mathrm{HHS}$ noted that the proposed rule would "serve the policy goal of greater transparency in how premium dollars are used and provide an additional incentive for issuers that already met the minimum standard to achieve the highest MLR possible."214 Insurers, however, objected to the disclosure requirement, urging that it would burden them unnecessarily while providing little useful information to consumers. ${ }^{215}$ HHS' final rule adopts a compromise, requiring insurers that meet or exceed the applicable MLR to simply provide policyholders and subscribers with a one-time notice, on or after July 1, 2012,

(discussing how insurers' premium revenues are divided between Medicare and other non-claim expenses); see U.S. Dep't. of Health \& Human Servs., Final Rule, Medical Loss Ratio Requirements Under the Patient Protection and Affordable Care Act, 77 Fed. Reg. 28,790 (May 16, 2012) (to be codified at 45 C.F.R. $\$ 158$ ) (summarizing that this amends the Public Health Service Act in regard to notice requirements).

208. Public Health Service Act $\$ 2718$ (b)(1)(A)(i), 42 U.S.C. $\$ 300 g g-18$ (2006).

209. Id; see Timothy Jost, Implementing Health Reform: The Minimum Loss Ratio \& Summary of Benefits and Coverage, HEALTH AFF. BLOG (May 13, 2012), http://healthaffairs.org/blog/2012/05/13/implementinghealth-reform-the-minimum-loss-ratio-summary-of-benefits-and-coverage/ (discussing employers who fail to meet a spending target must pay a rebate to their enrollees); Pear, supra note 65 (proposing adverse effects of the new health care law on companies' financial results).

210. See Jost, supra note 209 (stating the beginning of MLR rebates); KAISER FAMILY FOUND., INSURER REBATES UNDER THE MEDICAL Loss RATIO: 2012 ESTIMATES 1 (Apr. 2012), available at http://www.kff.org/ healthreform/upload/8305.pdf (stating that "by August of this year, insurance companies will be required to issue consumer rebates" if not in compliance with MLRs).

211. Jost, supra note 209; KAISER FAMILY FOUND., supra note 210, at 2 (noting an estimated $\$ 1.3$ billion in rebates in 2012).

212. Mark Halperin, Halperin's Take: Why ACA Rebates Are a Big Deal, TIME, May 11, 2012, http://thepage.time.com/2012/05/11/halperins-take-why-aca-rebates-are-a-big-deal.

213. See Medical Loss Ratio Requirements Under the Patient Protection and Affordable Care Act, 77 Fed Reg. at 28,791 (to be codified at 45 C.F.R. $\$ 158.251$ (a)(1)-(2)) (explaining that a notice requirement would serve a policy goal of greater transparency in how insurers spend money); Jost, supra note 209 (suggesting that the disclosure rule adopts a compromise between insurers and enrollees).

214. Medical Loss Ratio Requirements Under the Patient Protection and Affordable Care Act, 77 Fed. Reg. at 28,791 (to be codified at 45 C.F.R. $\$ 158.251$ (a)(1)-(2)).

215. Id. (noting that the prior years' MLRs are not necessarily a reliable indicator of plan performance and that the MLR data could confuse or mislead consumers into believing they are owed a rebate). 
about the MLR requirement. ${ }^{216}$ The notice will direct enrollees to the HHS website for further information about the insurer's specific MLR. ${ }^{217}$ HHS' rule spells out the precise language of the notice, which "must be prominently displayed in clear, conspicuous, 14 point bold type on the front of the plan document or as a separate notice." 218

These examples reveal a tension similar to the RDS write-off controversy. On the one hand, regulators seek to ensure availability of accurate, timely, reliable information regarding the financial status of regulated firms. On the other hand, the federal government seeks to control corporate political speech regarding essential public policy initiatives. In each example, the tension seems to resolve in favor of accurate disclosure and against speech regulation. In the example of constitutional challenges to the minimum essential coverage requirement, the legal merits prevailed over the perceived political rhetoric (at least for the commerce power argument). In the example of the postACA SEC disclosure controversy, which was the focus of our study, the firms' financial data and accounting standards prevailed over attempts by Congress and the Administration to politicize the issue. It remains to be seen whether the federal government will be successful in its more recent attempts to compel corporate political speech by health insurers in order to boost public opinion of the ACA. The compromise version of the MLR notice requirement is consistent with the observed pattern that integrity of regulated disclosures will prevail over attempts to politicize corporate speech. We conclude where we began: expressing concern for the government's potential to chill, distort, or otherwise discredit accurate financial disclosures by damning them as political gamesmanship.

\section{CONCLUSION}

This empirical study of public companies' SEC disclosure statements in the immediate wake of the ACA's enactment offers novel insights for the regulation of corporate political speech and the integrity of financial disclosures. SEC Form 8-K, with its rapid disclosure policy and materiality trigger, offers a unique forum for political speech, both allowing and requiring firms to comment publicly on the financial impact of new legislation as soon as it is enacted. Despite the potential for SEC filings to have a double effect as political speech, we conclude that the government should exercise restraint in discrediting the disclosures as political and, therefore, improper. Just as regulators should not suppress otherwise accurate, required corporate disclosures because they tend to criticize government policies, they should exercise caution in compelling corporate speech to advance a political agenda.

216. Id.

217. Id.

218. Id. at 28,797 (to be codified at 45 C.F.R. $\S 158.251(\mathrm{a})(4)$ ). 
*** 